University of South Florida

DIGITAL COMMONS

@ UNIVERSITY OF SOUTH FLORIDA
Digital Commons @ University of

South Florida

7-1-2005

\title{
Update Methodology for ADA Demand Estimates: Lessons Learned
}

CUTR

Follow this and additional works at: https://digitalcommons.usf.edu/cutr_nctr

\section{Recommended Citation}

"Update Methodology for ADA Demand Estimates: Lessons Learned," National Center for Transit Research (NCTR) Report No. CUTR-NCTR-RR-2004-10, Center for Urban Transportation Research, University of South Florida, 2005.

DOI: https://doi.org/10.5038/CUTR-NCTR-RR-2004-10

Available at: https://scholarcommons.usf.edu/cutr_nctr/183

This Technical Report is brought to you for free and open access by the National Center for Transit Research (NCTR) Archive (2000-2020) at Digital Commons @ University of South Florida. It has been accepted for inclusion in Research Reports by an authorized administrator of Digital Commons @ University of South Florida. For more information, please contact digitalcommons@usf.edu. 
Update Methodology for ADA Demand Estimates:

Lessons Learned

July 2005
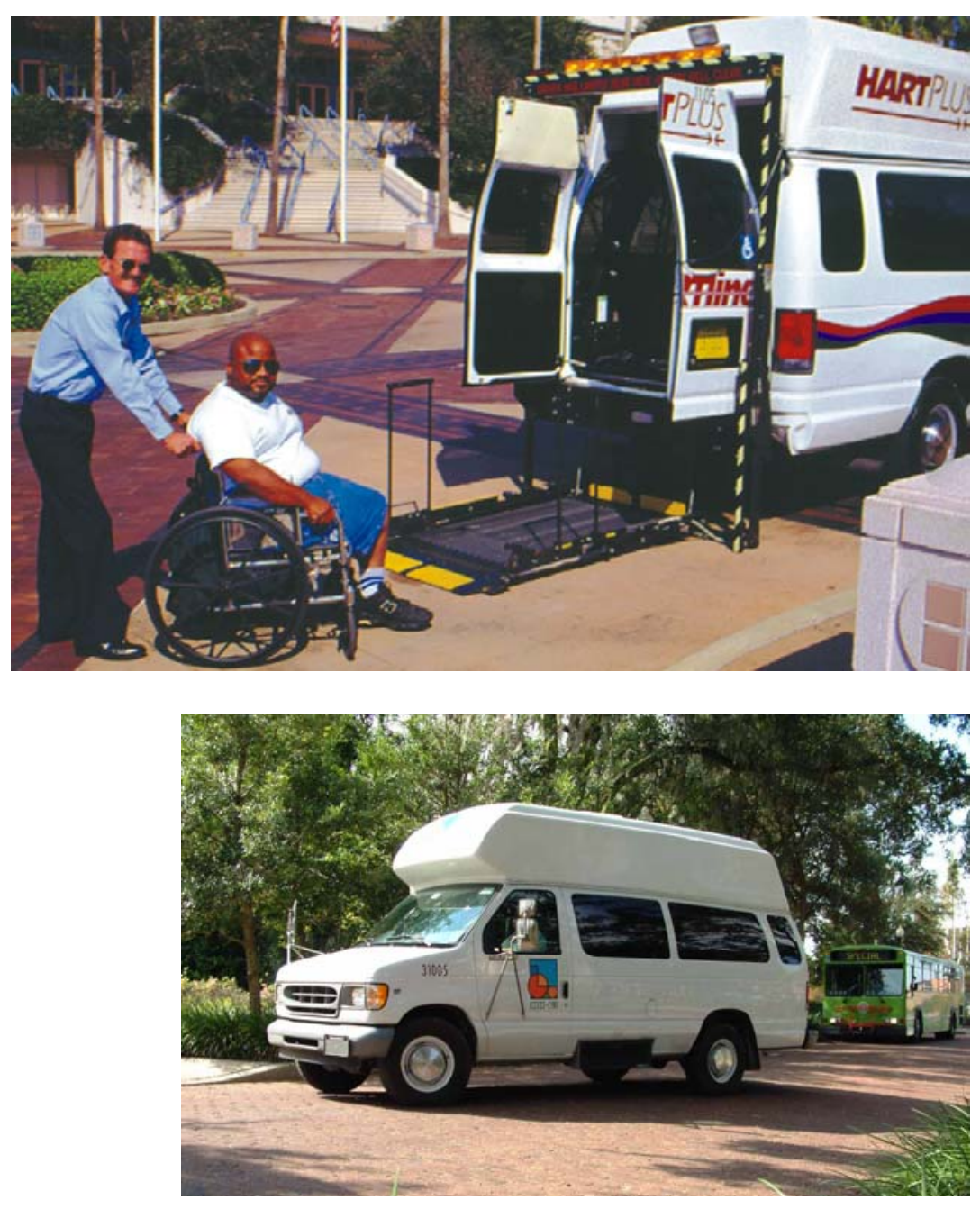


\begin{tabular}{|c|c|c|c|}
\hline $\begin{array}{l}\text { 1. Report No. } \\
\text { NCTR Project 576-13; } \\
\text { FDOT Project BD 549 - } 8\end{array}$ & 2. Government Accession No. & \multicolumn{2}{|c|}{ 3. Recipient's Catalog No. } \\
\hline \multirow{2}{*}{\multicolumn{2}{|c|}{$\begin{array}{l}\text { 4. Title and Subtitle } \\
\text { Update Methodology for ADA Demand Estimates: Lessons Learned }\end{array}$}} & \multicolumn{2}{|l|}{$\begin{array}{l}\text { 5. Report Date } \\
\text { July } 2005\end{array}$} \\
\hline & & \multicolumn{2}{|c|}{ 6. Performing Organization Code } \\
\hline \multicolumn{2}{|l|}{$\begin{array}{l}\text { 7. Author(s) } \\
\text { Thole, Cheryl; Felicia Harvey }\end{array}$} & \multicolumn{2}{|c|}{ 8. Performing Organization Report No. } \\
\hline \multirow{2}{*}{\multicolumn{2}{|c|}{$\begin{array}{l}\text { 9. Performing Organization Name and Address } \\
\text { National Center for Transit Research (NCTR) } \\
\text { University of South Florida, CUT } 100 \\
4202 \text { East Fowler Avenue, Tampa, FL } 33620\end{array}$}} & \multicolumn{2}{|c|}{ 10. Work Unit No. } \\
\hline & & \multicolumn{2}{|c|}{$\begin{array}{l}\text { 11. Contract or Grant No. } \\
\text { DTRS98-G-0032 }\end{array}$} \\
\hline \multirow{2}{*}{\multicolumn{2}{|c|}{$\begin{array}{l}\text { 12. Sponsoring Agency Name and Address } \\
\text { Florida Department of Transportation } \\
605 \text { Suwannee Street } \\
\text { Tallahassee, FL } 32399\end{array}$}} & \multicolumn{2}{|c|}{ 13. Type of Report and Period Covered } \\
\hline & & \multicolumn{2}{|c|}{ 14. Sponsoring Agency Code } \\
\hline \multicolumn{4}{|l|}{ 15. Supplementary Notes } \\
\hline \multicolumn{4}{|c|}{$\begin{array}{l}\text { 16. Abstract } \\
\text { The current and accepted standard for determining local impacts of ADA is found in the ADA Paratransit Handbook } \\
\text { published in September } 1991 \text { (UMTA-MA-06-0206-91-1). This methodology was developed from surveys taken in 1978 } \\
\text { and 1987, along with } 1980 \text { U.S. Census data. The current methodology may represent the population that is potentially } \\
\text { ADA-eligible; however, it does little to assist transit agencies in determining actual paratransit demand. Additionally, } \\
\text { transit systems now have vehicles that can accommodate many disabilities, making it possible for many of the potential } \\
\text { ADA-eligible population to ride the fixed route. Information regarding methodologies used to forecast ADA paratransit } \\
\text { demand among transit agencies have been gathered in order to provide an understanding of certain practices and an } \\
\text { assessment as to which methodologies are to be considered best practices has been completed. }\end{array}$} \\
\hline $\begin{array}{l}\text { 17. Key Words } \\
\text { Public transit, ADA, paratransit, ridership } \\
\text { forecasting, demand estimation }\end{array}$ & \multicolumn{3}{|c|}{$\begin{array}{l}\text { 18. Distribution Statement } \\
\text { Available to the public through the National Technical Information Service (NTIS), } \\
5285 \text { Port Royal Road, Springfield, VA 22161, (703) 487-4650, } \\
\text { http://www.ntis.gov/, and through the NCTR website at http://www.nctr.usf.edu/. }\end{array}$} \\
\hline $\begin{array}{l}\text { 19. Security Classif. (of this report) } \\
\text { Unclassified }\end{array}$ & $\begin{array}{l}\text { 20. Security Classif. (of this page) } \\
\text { Unclassified }\end{array}$ & $\begin{array}{l}\text { 21. No. of pages } \\
66\end{array}$ & 22. Price \\
\hline
\end{tabular}

Form DOT F 1700.7 (8-69) 


\title{
Update Methodology for ADA Demand Estimates: Lessons Learned
}

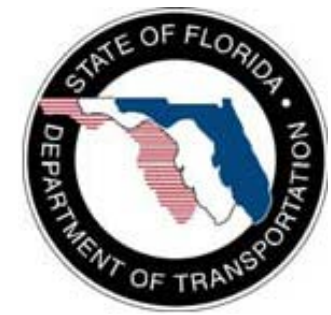

State of Florida Department of Transportation

Public Transit Office

605 Suwannee Street

Tallahassee, FL 32399-0450

(850) 414-4500

Project Manager:

Tara Bartee
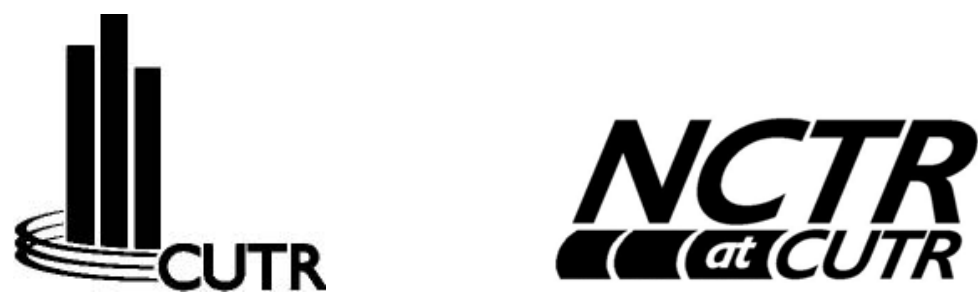

\author{
National Center for Transit Research \\ Center for Urban Transportation Research \\ University of South Florida \\ 4202 E. Fowler Avenue, CUT 100 \\ Tampa, FL 33620-5375
}

(813) 974-3120

\author{
Project Director: \\ Dennis Hinebaugh, Transit Program Director \\ Principle Investigator: \\ Cheryl Thole, Research Associate \\ Project Staff: \\ Felicia Harvey, Graduate Research Assistant \\ Lisa Maitland, Program Assistant
}

The opinions expressed in this publication are those of the authors and not necessarily those of the U.S. Department of Transportation or the State of Florida Department of Transportation. 


\section{TABLE OF CONTENTS}

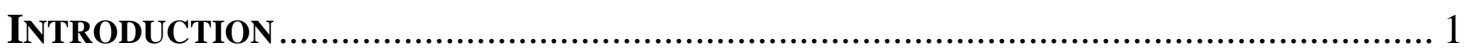

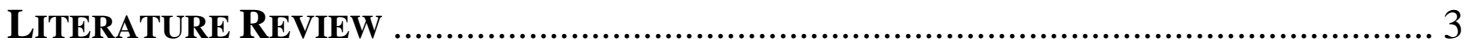

Forecasting Methods.................................................................................... 3

Policy Choices Affecting Paratransit Demand …………….................................. 6

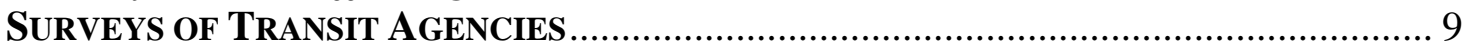

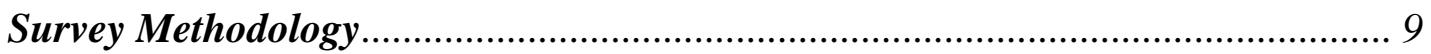

SURVEY RESPONSES AND LOCATION DATA.......................................................... 11

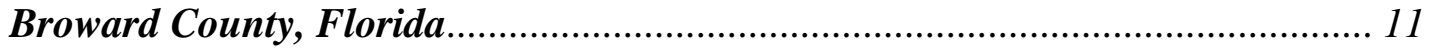

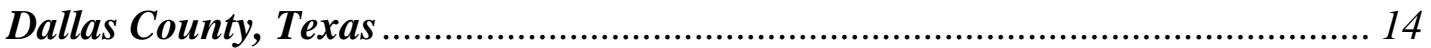

Escambia County, Florida ............................................................................ 17

King County, Washington ................................................................................. 21

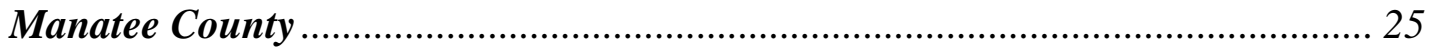

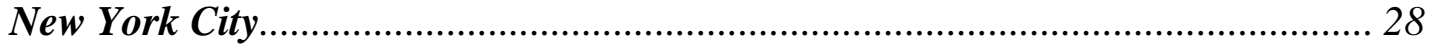

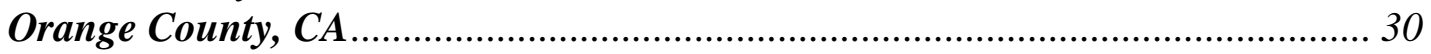

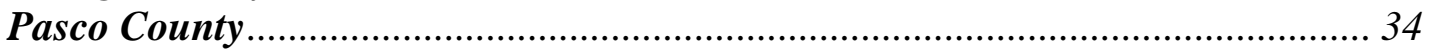

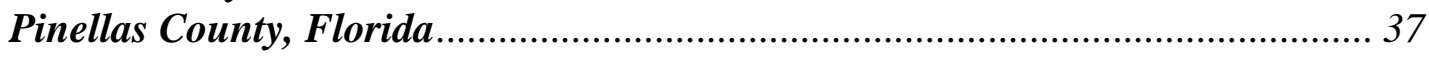

Polk County ................................................................................................. 40

Regional Transit System - Alachua County …………….................................... 43

Sarasota County .......................................................................................... 46

Volusia County - VOTRAN …………………………................................. 52

SUMMARY OF SURVEY RESULTS ............................................................................ 56

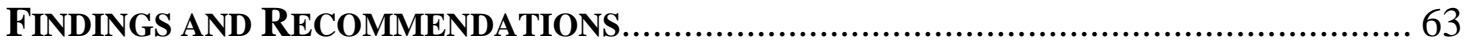




\section{LIST OF TABLES}

Table 1. 2002 Estimates of Persons by Age Group in Broward County ......................... 11

Table 2. Persons Aged 65 and Older Population and Projections in Broward County ... 12

Table 3. Paratransit Ridership Data, BCT ................................................................. 12

Table 4. Number of Paratransit Trips Made per Year, BCT .......................................... 13

Table 5. Costs of Operating ADA Paratransit Service, BCT ........................................... 13

Table 6. Paratransit Ridership Data, DART ............................................................... 14

Table 7. Number of Paratransit Trips Made per Year, DART......................................... 15

Table 8. Costs of Operating ADA Paratransit Service, DART........................................ 15

Table 9. Forecasted Values for ADA Ridership, DART .............................................. 16

Table 10. 2002 Estimates of Persons by Age Group in Escambia County..................... 18

Table 11. Persons Aged 65 and Older Population and Projections in Escambia County 18

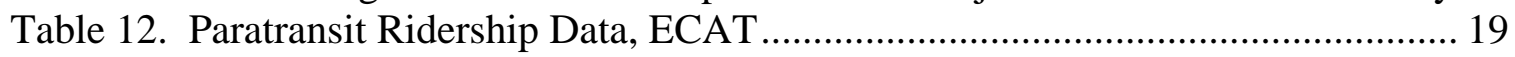

Table 13. Number of Paratransit Trips Made per Year, ECAT ….................................... 19

Table 14. Costs of Operating ADA Paratransit Service, ECAT ...................................... 20

Table 15. Forecasted Values for ADA Ridership, ECAT............................................. 20

Table 16. Paratransit Ridership Data, King County .................................................... 21

Table 17. Number of Paratransit Trips Made per Year, King County............................. 22

Table 18. Costs of Operating ADA Paratransit Service, King County............................. 23

Table 19. Forecasted Values for ADA Ridership, King County .................................... 24

Table 20. 2002 Estimates of Persons by Age Group in Manatee County........................ 25

Table 21. Persons Aged 65 and Older Population and Projections in Manatee County.. 26

Table 22. Paratransit Ridership Data, MCAT............................................................ 26

Table 23. Number of Paratransit Trips Made per Year, MCAT ...................................... 27

Table 24. Costs of Operating ADA Paratransit Service, MCAT ..................................... 27

Table 25. Paratransit Ridership Data, NYC Transit ...................................................... 28

Table 26. Number of Paratransit Trips Made per Year, NYC Transit............................ 29

Table 27. Paratransit Ridership Data, OCTA …............................................................ 30

Table 28. Number of Paratransit Trips Made per Year, OCTA...................................... 31

Table 29. Forecasted Values for ADA Ridership, OCTA ............................................. 33

Table 30. 2002 Estimates of Persons by Age Group in Pasco County ............................ 34

Table 31. Persons Aged 65 and Older Population and Projections in Pasco County ...... 35

Table 32. Paratransit Ridership Data, PCPT................................................................ 35

Table 33. 2002 Estimates of Persons by Age Group in Pinellas County......................... 37

Table 34. Persons Aged 65 and Older Population and Projections in Pinellas County... 38

Table 35. Number of Paratransit Trips Made per Year, PSTA....................................... 39

Table 36. Costs of Operating ADA Paratransit Service, PSTA....................................... 39

Table 37. 2002 Estimates of Persons by Age Group in Polk County .............................. 40

Table 38. Persons Aged 65 and Older Population and Projections in Polk County ........ 41

Table 39. Paratransit Ridership Data, Polk County Intercity Transit ............................ 42

Table 40. 2002 Estimates of Persons by Age Group in Alachua County ...................... 43

Table 41. Persons Aged 65 and Older Population and Projections in Alachua County .. 44

Table 42. 2002 Estimates of Persons by Age Group in Sarasota County ...................... 46

Table 43. Persons Aged 65 and Older Population and Projections in Sarasota County.. 47 
Table 44. Paratransit Ridership Data, SCAT

Table 45. Number of Paratransit Trips Made per Year, SCAT ………………………..... 48

Table 46. Costs of Operating ADA Paratransit Service, SCAT ……………………........ 48

Table 47. Forecasted Values for ADA Ridership, SCAT ................................................... 49

Table 48. 2002 Estimates of Persons by Age Group in Volusia County .......................... 52

Table 49. Persons Aged 65 and Older Population and Projections in Volusia County ... 53

Table 50. Number of Paratransit Trips Made per Year, VOTRAN.................................. 54

Table 51. Costs of Operating ADA Paratransit Service, VOTRAN................................ 54

Table 52. Forecasted Values for ADA Ridership, VOTRAN ........................................ 55

Table 53. Data and Forecasting Methods Utilized by Agencies for Estimating Demand 56

Table 54. Difference between Actual Trips and Forecasted Demand, DART ................. 57

Table 55. Difference between Actual Trips and Forecasted Demand, King County ...... 58

Table 56. Difference between Actual Trips and Forecasted Demand, OCTA ................. 60

Table 57. Difference between Actual Trips and Forecasted Demand, SCAT .................. 60

Table 58. Difference between Actual Trips and Forecasted Demand, VOTRAN............ 61 


\section{Introduction}

As part of its National Center for Transit Research (NCTR) Program, the Center for Urban Transportation Research (CUTR) conducted research for the Florida Department of Transportation (FDOT) to investigate how transit agencies forecast their demand for paratransit ridership, and to evaluate the types of methods used to accomplish this task.

Paratransit services, also known as demand responsive transit, provide an alternative mode of transportation for persons that are not able to make their trip on fixed-route transit systems, due to a disability. The provision of these services became mandatory with the implementation of the Americans with Disabilities Act of 1990 (ADA), which required the provision of accessible transportation for persons with disabilities in the same areas in which other public transportation is provided. Specifically, ADA paratransit service provides service to locations within $3 / 4$ miles of a fixed-route service.

Currently used methodologies to forecast the demand for paratransit systems and an assessment of the success of these methodologies are presented in this report. In addition, this report also develops recommendations to assist transit agencies in the evaluation of their methodologies used to forecast their demand.

This project included three distinct tasks that were designed to achieve the objectives listed above. First, a literature review was conducted pertaining to forecasting demand for paratransit systems. CUTR reviewed and summarized previous studies and discussions related to demand forecasting. A significant amount of research within CUTR has been dedicated to exploring paratransit demand and the methods used to estimate the future ridership. Based on the results of the literature review, a series of currently used methodologies related to forecasting paratransit demand are identified in the report. As part of the first task of this project, CUTR collected data regarding paratransit systems, including information such as the number of ADA certified users and the number of ADA paratransit trips made per year. The costs, service hours, and users were gathered as associated data. Previous and current demographic Census data was collected to coincide with the service area of the transit agencies included in the report in order to provide a background of the area. 
During the second task, further information regarding the methodologies used to forecast paratransit demand was collected from the participating transit agencies. Staff also gathered information regarding agency's process for determining paratransit eligibility.

The information gathered in the first and second tasks were then analyzed in an attempt to develop a comprehensive reference of ADA practices among transit agencies. This information was then evaluated in an effort to determine which agencies employed the best practices for demand estimation.

The final task of this research compiled the results of all the previous tasks to develop a synthesis of the best practices in the evaluation of forecasting paratransit demand. Successful endeavors are highlighted, as well as challenges facing these types of methodologies. Overall, the findings of this study seek to isolate specific characteristics or conditions that attribute to success, as well as those that present challenges to overall effectiveness and success. In addition, recommendations are offered related to the appropriateness of using particular data in the forecasting process.

The results of this study are largely based on the qualitative results of the surveys. Definitive results derived through quantitative analysis were minimally achieved because of the lack of recording of data within transit agencies. The value of the results is in the experiences and lessons learned from the agencies that participated in the study. One notable result, however, is that when evaluating the methodologies used by transit agencies, it was understood that a local and historical understanding of the internal operations and experiences are perhaps the most valuable asset for agencies when forecasting the paratransit demand.

It should also be noted that the original intention of this project was to formulate a methodology that transit agencies may use to forecast paratransit demand. Prior to the commencement of the project, however, it was learned that a similar project with this objective was proposed by the Transit Cooperative Research Program (TCRP). The objectives of the TCRP project would be to conduct a more comprehensive evaluation of transit agencies throughout the U.S. and determine a methodology that may be applied by each agency. It was therefore determined that the task of developing a methodology would not be included in the scope of this project. 


\section{Literature Review}

As discussed previously in the Introduction section, as part of the analysis, CUTR conducted an in-depth literature search on demand forecasting and paratransit systems. Although there was a vast amount of prior research on demand forecasting for fixed-route systems, literature dedicated to demand forecasting for paratransit systems was somewhat limited. The following paragraphs summarize these studies.

Demand responsive transit, also referred to as paratransit, includes services where a vehicle does not operate on a fixed-route, but travels to particular locations based on service requests. Regulations implementing the Americans with Disabilities Act (ADA) require that some form of paratransit service be made available for persons who, because of a disability, cannot access or use conventional transit services. This complementary service must be available at the same times and in relatively the same locations as conventional service. Specifically, ADA paratransit service provides service to locations within $3 / 4$ miles of a fixed-route service.

Since the 1980s the transit industry has experienced a large increase in the number of paratransit systems in the United States and the average size of those systems. One of the challenges faced by transit agencies today is anticipating the continuing increases in trip growth and demand. Unfortunately, little is known about the demand for paratransit systems, how the characteristics of the local population affect the demand, or how the systems change over time.

\section{Forecasting Methods}

Planning and budgeting for paratransit services is an important issue, as public transit agencies are often working with a limited budget and mandated by law to provide certain levels of service. Methods for estimating demand are essential to developing accurate budgets and managing costs. Although most systems need to accomplish this task, transit agencies do not appear to be in consensus on how to accomplish this measurement. According to the reviewed literature, there are five different methods utilized to assess the demand for paratransit use among agencies. These five methods include the use of historical data, surveys, intuitive comparison with other systems, cross-sectional analysis, and time-series econometric analysis. 


\section{Survey Method}

The survey method of forecasting demand allows users to respond to questions regarding paratransit services, such as their frequency of use of the system, and the types of trips riders take. There are many advantages of the survey method, including its ability to gather local data. This information assists policymakers in the decision making process regarding system funding and other related factors. A survey can also identify how individuals will respond to changes in service, allowing agencies to make educated decisions about the service they provide. Two disadvantages associated with the survey method are the likelihood of data to be error-prone, and the inability to accurately predict how the number of trips will increase over time due to rider's inability to accurately assess how their travel behavior would change if system changes would occur.

In Seattle, a survey was done to estimate the number of eligible passengers and the number of trips they would make if an ADA-compliant system was in place (Koffman 1997). A telephone screening questionnaire was administered to 3,920 households that were randomly dialed, which provided 182 individuals that would be eligible for ADA paratransit, 712 individuals who would be eligible for OPTIONS (a service for lowincome elderly and low-income disabled), with 125 eligible for both. Detailed interviews were administered to 420 OPTIONS-eligible people, with 87 of them also being eligible for ADA paratransit. With the received survey results, they were able to provide detailed information about:

- Trips by ADA-only, OPTIONS-only, and ADA- and OPTIONS- eligible riders;

- The impact of the planned fare increase;

- The impact of alternative trip limits on OPTIONS-only ridership;

- A division of trips between those already made but shifted from other modes and additional trips created by the new service;

- An estimate of trip making by trip purpose, time of day, and day of week;

- Trips from and to major sub areas of the county; and

- The percentage of trips that would involve an attendant or companion.

New York conducted a similar survey and they also surveyed current paratransit users. This survey was used to estimate the eligible population and the percent that would register for service (Koffman 1997). Their survey produced the following estimates: 
- Percentage of the population that is ADA eligible

- Percentage who would register for advance reservation service and/or subscription service

- Percentage who would regularly use advance reservation service, both interborough and intraborough

- Number of trips per advance reservation or subscription user per month, both interborough and intraborough.

\section{Time-series Econometric Analysis}

The time-series econometric analysis model consists of using historical data that takes into account changes in service availability, fares, hours and other variables to construct an equation that will allow one to predict how changes in those factors would affect ridership. This method is most appropriately used when drastic changes are unlikely to occur in the future (in contrast with the historical data). Both New York and Seattle used econometric analysis of time-series data by using a two-equation system to describe the relationship between paratransit demand and the availability of service. Seattle also compared their data from both the surveys and econometric analyses with other systems that were at, or close to, ADA compliance.

The Orange County Transportation Authority (OCTA) hired consultants to create a timeseries model that would forecast ridership over five years (Menninger-Mayeda 2004). Specifically, the model was designed to predict daily ADA one-way passenger boardings. The model can calculate ridership, as well as revenue hours and miles for peak periods. The most relevant predictor was the difference in demand for weekdays (non-holiday) and weekends/holidays, followed by ridership increase over time. Time series analysis of 1.8 million boardings over a 34-month period, a peer survey, census data analysis, and community outreach efforts were used to develop their model.

The model used by OCTA operates under the premise that the underlying assumptions used to construct the model will not change. When change does occur, there are three methods suggested to correct the model:

- If the difference between actual and predicted estimates is temporary, the predicted estimate can be adjusted by adding or subtracting an average daily demand.

- If the difference is permanent, an additional variable may be added. 
- If the actual ridership increases or decreases at a rate different than initially predicted, the model-building analysis could be run again, adjusting the weight given to the more recent past.

Benchmarks that can help identify changes in trip levels, frequency, and rate of change were also identified. They include; rider age distribution, rider age distribution by disability code, certification rates by month and jurisdiction, purpose of trips, distance of trips, and time of day of trips.

\section{Cross-Sectional Econometric Analysis}

Cross-sectional econometric analysis is similar to time-series econometric analysis, except that this analysis also draws information from other systems. The information that is compared is that from a predetermined time frame. This type of analysis is a relatively simple and inexpensive way of estimating the effect of changes in service and policies. The limitations of this type of analysis are related to the accuracy level of information that is collected in a large survey.

The New York study also used a cross-sectional econometric analysis to estimate a regression model as a function of various variables that affect ridership. The model was based on a survey of 160 paratransit systems, and considered variables such as fare, advance reservation requirements, eligibility rules, and vehicle hours of service.

\section{Policy Choices Affecting Paratransit Demand}

The nature of policy decisions has a direct effect on the demand for paratransit service. Policy decisions regarding the eligibility process, transfers and travel time, fare increases, capacity constraints, and response time each play a role in determining how frequently paratransit services are being utilized.

\section{Eligibility Process}

Most agencies are choosing to exceed the minimum requirements and are not strict with their eligibility process. An example of this is many transit agencies do not enforce distinctions between fully and conditionally eligible certified users. Efforts in King County, Washington, however, have found that factors associated with the eligibility process have a significant effect on the demand posed for paratransit service. A study conducted by Nelson/Nygaard was conducted to evaluate if key changes that were 
implemented in the eligibility process had an effect on demand (Weiner 2003). The changes that were applied included the requirement of a pre-application process for applicants, a 100 percent telephone interview follow-up, and an increase in the proportion of in-person functional evaluation through contracted experts from a local medical center. An evaluation of the effects of these changes is provided below.

- On average, new applicants are being added to the ADA certified rolls at half the rate of what was previously recorded

- If the application rate had continued at the rate that was expected prior to the changes, an additional 8,000 people would be considered eligible within three years.

- The recertification process was expected to result in the removal of 3,200 people by the end of 2003 .

\section{Transfers and Travel Time}

The majority of agencies provide direct paratransit service among all destinations within their service areas. There are no requirements, however, that prevents the establishment of service zones and transfer points as long as the trip length does not become excessive. Requiring able individuals to make part of their trip using fixed-route service may decrease the demand on paratransit services.

\section{Fare Increases}

During a survey conducted by King County Metro, the effects of fare increases were evaluated. The survey, which was conducted over the telephone, asked respondents if they would access paratransit service if the fare was $\$ .25 /$ trip or $\$ 3.75 /$ month. Those that responded that they would likely make a trip using the service were again contacted later and asked if they would still access the system if the fare was increased to $\$ 0.85 /$ trip or $\$ 30.50$ /month. The results of the survey indicated that a planned fare increase would eventually decrease demand by 62 percent.

\section{Response Time}

Some transit agencies exceed the minimum requirements by providing same-day or immediate-response service. Some of these agencies perceive this policy as having cost advantages, such as those that provide subsidized taxi service as the form of paratransit. The elimination of this practice may decrease the costs and demand on paratransit services. 


\section{Capacity Constraints}

Although many transit agencies are making efforts to not have zero trip denials, there is not a requirement to do this. Regulations only prohibit "substantial numbers of trip denials or missed trips", "substantial numbers of trips with excessive trip lengths”, and “substantial number of significantly untimely pickups” (USDOT). Policy choices made in an effort to comply with these recommendations will affect the amount of demand posed on paratransit services.

This section provided a summary of methods used to forecast paratransit demand and policies that affect the demand that is posed on these services. The next section of this report summarizes the survey effort undertaken as part of this project. 


\section{Surveys of Transit Agencies}

A major effort of this project was a survey of transit agencies within the State of Florida and a few throughout the United States. Based on the findings from the previous tasks of this study, a survey was developed and administered to determine the specific components of and issues faced by transit agencies on the use of methodologies for forecasting paratransit demand. Specific topics that were addressed were system characteristics, the process of determining eligibility of ADA users, the costs associated with paratransit trips, the number of certified ADA users, methodologies used to forecast demand, and recorded values for previous estimations. The results of the survey, along with the results of other tasks, were used in the final task of this project to develop a synthesis of best practices in the development of methodologies for forecasting demand. This task consisted of the development and conduct of surveys with transit agencies that provide paratransit services. The purpose was to collect information related to the nature of any relationship between actual demand and area/system characteristics.

\section{Survey Methodology}

During summer and fall 2004, a total of 13 agencies were surveyed for this effort. Surveys were conducted by mail and/or telephone using a prepared list of questions/topics that were developed using the results of the first two tasks of this project: the literature review and gathering of area information. The survey questions included the following topics:

- The number of ADA certified users

- The number of ADA/paratransit trips per year

- The number of certified ADA users that access fixed-route

- The eligibility process for determining certified ADA users

- Costs and operational information associated with paratransit service

- The methods used to forecast ADA/paratransit trips

The transit agencies that participated in this survey are listed below. An effort to obtain information from transit agencies within the State of Florida was made, as well as agencies located outside of Florida upon the recommendation of staff of the American Public Transportation Association (APTA). The low response level among agencies located in the state of Florida may likely be attributable to hurricanes that hit the state during the survey period. Following the list of participating agencies are summaries of each agency's response as well as information gathered regarding the area in which 
services are provided, such as population projections and the number of persons over age 65. This information is important, as it is necessary for transit agencies to consider the characteristics of the area of which they are serving.

- Broward County Transit (Ft. Lauderdale, FL)

- Dallas Area Regional Transit (Dallas, TX)

- Escambia County Area Transit (Pensacola, FL)

- King County Metro (Seattle, WA)

- Manatee Area County Transit (Bradenton, FL)

- New York City Transit (NY)

- Orange County Transit Authority (Orange, CA)

- Pasco County Public Transportation (Port Richey, FL)

- Pinellas Suncoast Transit Authority (Clearwater, FL)

- Polk County Intercity Transit (Lakeland, FL)

- Regional Transit System (Gainesville, FL)

- Sarasota County Area Transit (Sarasota, FL)

- VOTRAN (Daytona Beach, FL) 


\section{Survey Responses and Location Data}

\section{Broward County, Florida}

Location

Broward County is located on the east coast of Florida between Palm Beach and MiamiDade counties. With 1,381 persons per square mile, the County is the second most dense in the State of Florida.

\section{Population and Demographics}

In 2000, Broward County was the second most populous County in the state with 1,623,018 residents. This is approximately 10 percent of the state's population. There are 30 municipalities in the County, with the City of Ft. Lauderdale having the greatest population (152,397), followed by Hollywood (139,357), Pembroke Pines $(137,427)$, and Coral Springs $(117,549)$ (BEBR, 2003). There are 129,437 residents living in the unincorporated area.

From 1990 to 2000, the county experienced an increase in population of 29.3 percent. Estimates based upon the U.S. Census show a 2.84 percent change in the population between 2000 and 2002 (BEBR, 2003). Population projections for the County show the population to increase to $1,910,100$ by 2010 and 2,207,000 by 2020 .

The median age of residents within Broward County is 38.6 compared to the median age of 39.4 for the state of Florida. The median age is projected to increase to 43.6 by 2020 (BEBR, 2003). As seen in Table 1, approximately 40 percent of the population is 45 years of age and older.

Table 1. 2002 Estimates of Persons by Age Group in Broward County

\begin{tabular}{|l|c|c|}
\hline Age & Population & Percent \\
\hline $\mathbf{0 - 1 4}$ & 325,448 & 19.5 \\
\hline $\mathbf{1 5 - 2 4}$ & 188,575 & 11.3 \\
\hline $\mathbf{2 5 - 4 4}$ & 499,854 & 29.9 \\
\hline $\mathbf{4 5 - 6 4}$ & 388,971 & 23.3 \\
\hline 65 and over & 266,305 & 16.0 \\
\hline Total & $1,669,153$ & 100.0 \\
\hline
\end{tabular}

*Source: Bureau of Business and Economic Research, 2003 
The percentage of residents in the County aged 65 and older is 16 percent. As shown in Table 2, about 50 percent of persons 65 and older are between the ages of 65 and 74 .

Table 2. Persons Aged 65 and Older Population and Projections in Broward County

\begin{tabular}{|l|c|c|c|c|c|c|}
\hline Age & $\begin{array}{c}\text { Population } \\
\mathbf{2 0 0 2}\end{array}$ & Percent & $\begin{array}{c}\text { Projections } \\
\mathbf{2 0 1 0}\end{array}$ & Percent & $\begin{array}{c}\text { Projections } \\
\mathbf{2 0 2 5}\end{array}$ & Percent \\
\hline $\mathbf{6 5 - 7 4}$ & 119,668 & 44.9 & 109,329 & 49.3 & 177,444 & 54.4 \\
\hline $\mathbf{7 5 - 8 4}$ & 102,509 & 38.5 & 75,887 & 34.2 & 109,091 & 33.5 \\
\hline $\mathbf{8 5}$ and over & 44,128 & 16.6 & 36,510 & 16.5 & 39,355 & 12.1 \\
\hline Total & 266,305 & 100 & 221,726 & 100 & 325,890 & 100 \\
\hline
\end{tabular}

*Source: Bureau of Business and Economic Research, 2003

Public Transportation

The Broward County Mass Transit Division (BCT) is part of the Broward County Community Services Department. Fixed-route motorbus services are offered throughout the County by the Division. These services are provided directly and through contracts. Connections to other transit services, including Miami-Dade Transit, Palm Tran, and TriRail are also provided. Paratransit service is provided through private contractors. BCT’s service area population for FY 2002 was 1,623,018. BCT’s weekday span of service is 19.9 hours.

\section{Paratransit Services}

Broward County has 16,270 certified ADA users in their service area, with approximately 34.4 million annual riders of the fixed route. Approximately 98 percent of certified ADA users only use paratransit service and 2 percent of users do not live in the service area.

Table 3. Paratransit Ridership Data, BCT

\begin{tabular}{|c|c|}
\hline Year & \# of Certified ADA Users \\
\hline 2000 & 16,794 \\
\hline 2001 & 15,662 \\
\hline 2002 & 15,849 \\
\hline 2003 & 16,045 \\
\hline 2004 & 16,270 \\
\hline
\end{tabular}


Table 4. Number of Paratransit Trips Made per Year, BCT

\begin{tabular}{|c|c|}
\hline Year & \# ADA Trips/Year \\
\hline 2000 & 719,660 \\
\hline 2001 & 700,517 \\
\hline 2002 & 605,087 \\
\hline 2003 & 633,483 \\
\hline \multicolumn{2}{|c|}{ Source: CUTR Survey }
\end{tabular}

To determine ADA eligibility, Broward County uses a full, in-person, functional assessment by a $3^{\text {rd }}$ party contractor.

The fare per ADA trip is $\$ 2.00$, while the actual cost per trip is approximately $\$ 20.78$. The hours for ADA paratransit service are comparable to the hours for fixed-route, with services running approximately 4:30 a.m. - 12:30 a.m. ADA services are contracted out to 4 local contractors, AAA, Handivan, Village Car, and Area Aging. There was no information available about the composition of these transit fleets. The agency compensates for ADA paratransit services when hours vary among routes by allowing for the broadest time window.

Table 5. Costs of Operating ADA Paratransit Service, BCT

\begin{tabular}{|c|c|}
\hline Year & $\begin{array}{c}\text { Cost/Sedan } \\
\text { Revenue Hour }\end{array}$ \\
\hline $\mathbf{2 0 0 0}$ & $\$ 14.54$ \\
\hline $\mathbf{2 0 0 1}$ & $\$ 15.20$ \\
\hline $\mathbf{2 0 0 2}$ & $\$ 15.64$ \\
\hline $\mathbf{2 0 0 3}$ & $\$ 16.98$ \\
\hline
\end{tabular}

Source: CUTR Survey

Methodology for Forecasting Paratransit Demand

BCT uses historical information to forecast their demand of paratransit ridership. The historical data is evaluated, and a five percent increase is applied to the previous year's value. 


\section{Dallas County, Texas}

Population and Demographics

The U.S. Census Bureau estimates the population of Dallas County, Texas at 2,284,096 which is approximately 10 percent of the state of Texas. There are 2,522.6 persons per square mile which is substantially greater than the state of Texas with only 79.6 persons per square mile. The size of the county is 880 square miles. Since 1990, the population of the county has increased 19.8 percent. Estimates based upon the U.S. Census show a 2.9 percent change in the population between 2000 and 2003 (U.S. Census Bureau, 2005). Dallas County has a relatively small population of persons 65 and older (8.1 percent). Approximately 27 percent of persons are under the age of 18.

\section{Public Transportation}

Dallas Area Rapid Transit (DART) is governed by a 15-member board which is appointed by member-city councils based on population. Services provided by DART include fixed-route motorbus, paratransit, and light rail transit, and the agency participates with Fort Worth Transportation Authority for the operation of a commuter rail transit line. There are 13 cities located within DART’s service area.

\section{Paratransit Service}

DART has an average number of 7,505 certified ADA users in their service area, with an unknown number of certified ADA users accessing fixed route services. The total number of annual riders of the fixed route service is 59.6 million (fiscal year 2003), which includes bus, light rail, commuter rail, and charter. On average, approximately 118 certified ADA users do not currently live within the service area.

Table 6. Paratransit Ridership Data, DART

\begin{tabular}{|c|c|}
\hline Year & \# of Certified ADA Users \\
\hline 2000 & 13,348 \\
\hline 2001 & 7,597 \\
\hline 2002 & 6,673 \\
\hline 2003 & 7,170 \\
\hline \multicolumn{2}{|c|}{ Source: CUTR Survey }
\end{tabular}


Table 7. Number of Paratransit Trips Made per Year, DART

\begin{tabular}{|c|c|}
\hline Year & \# ADA Trips/Year \\
\hline 2000 & 559,088 \\
\hline 2001 & 498,745 \\
\hline 2002 & 533,530 \\
\hline 2003 & 531,979 \\
\hline 2004 & 506,525 \\
\hline \multicolumn{2}{|c|}{ Source: CUTR Survey } \\
\hline
\end{tabular}

To determine ADA eligibility, DART uses the following process. The application is requested via phone, mail, or fax. The application is then mailed to the applicant. Once the completed application is received by the Certification Staff, an in-person assessment is scheduled. The assessment is done, eligibility is determined, and the applicant is notified of the results within 21 days.

The fare per ADA trip is $\$ 2.50$, while the actual cost per trip is approximately $\$ 30.87$. The fare for a single trip on fixed route services varies from \$1.25 to \$2.25 depending on the type of service. The hours for ADA paratransit service are comparable to the hours for fixed-route. ADA services are contracted out to ATC; they use 100 lift-equipped vans and 77 Ford Taurus sedans. The agency compensates for ADA paratransit services when hours vary among routes by paying the contractor based on a template of revenue hours, which are fixed. Two fixed routes were completely eliminated for fiscal year 2004, which did not significantly impact paratransit demand.

Table 8. Costs of Operating ADA Paratransit Service, DART

\begin{tabular}{|l|l|l|l|l|l|}
\hline Year & $\begin{array}{c}\text { Contractor } \\
\text { name or in- } \\
\text { house }\end{array}$ & \multicolumn{1}{|c|}{$\begin{array}{c}\text { Maintenance } \\
\text { Costs }\end{array}$} & $\begin{array}{c}\text { Operation } \\
\text { Costs }\end{array}$ & $\begin{array}{c}\text { Cost/Van } \\
\text { Revenue } \\
\text { Hour }\end{array}$ & $\begin{array}{c}\text { Cost/Sedan } \\
\text { Revenue Hour }\end{array}$ \\
\hline $\mathbf{2 0 0 0}$ & NA & NA & NA & NA & NA \\
\hline $\mathbf{2 0 0 1}$ & ATC & NA & $\$ 15,270,470$ & $\$ 28.46$ & $\$ 26.18$ \\
\hline $\mathbf{2 0 0 2}$ & ATC & NA & $\$ 16,860,113$ & $\begin{array}{l}\$ 29.89 \& \\
\$ 26.89\end{array}$ & $\$ 27.50$ \\
\hline $\mathbf{2 0 0 3}$ & ATC & NA & $\$ 16,424,389$ & $\$ 28.06$ & $\$ 28.46$ \\
\hline
\end{tabular}

Source: CUTR Survey

Methodology for Forecasting Paratransit Demand

Prior to 2003, DART did not have a specific methodology for forecasting paratransit demand. For 2004, however, a methodology was implemented to complete this task. This methodology is based upon previous values of ridership, productivity, and revenue hours. The methodology determines values for scheduled and actual ridership by 
multiplying a value of productivity by revenue hours on a monthly basis. The Board determines the productivity value for the scheduled and actual ridership. To forecast demand for 2004, DART used a scheduled productivity level of 1.68 riders per hour and an actual productivity level of 1.40 riders per hour. DART uses the value determined for actual ridership as their goal amount for that month. An example of how this data is determined each month is provided below, where 1.68 and 1.40 are productivity levels, and 38,076 is revenue hours.

Scheduled ridership equals: 1.68 x 38,076 = 63967

Actual ridership equals: $1.40 \times 38,076=533306$

Table 9. Forecasted Values for ADA Ridership, DART

\begin{tabular}{|l|l|l|}
\hline Year & $\begin{array}{l}\text { Estimated ADA Paratransit } \\
\text { Ridership }\end{array}$ & $\begin{array}{l}\text { Methodology Used to Determine } \\
\text { Number }\end{array}$ \\
\hline 2000 & 610,190 & Unknown \\
\hline 2001 & 515,200 & Unknown \\
\hline 2002 & 511,290 & Unknown \\
\hline 2003 & 594,440 & Unknown \\
\hline 2004 & 602,138 & Above methodology was used \\
\hline
\end{tabular}

A current discussion within DART is currently underway, in which the productivity level is questioned as a method for determining forecasted demand. DART believes that using a productivity level as a factor in this determination may decrease the value of service, by encouraging drivers to meet the expected demand (actual ridership), which may result in faster driving speeds and unsafe driving conditions. In order to remedy this situation, DART is currently revising their methodology of forecasting their demand by basing their value upon past ridership data. An assessment of this new methodology cannot yet be conducted as actual ridership values are yet to exist. An example of how the new methodology is being determined is provided below.

Year to date total (October 2004-March 2005) / 6 months $\mathbf{x} 12$ 


\section{Escambia County, Florida}

\section{Location}

Escambia County is located in the Northwestern corner of Florida, bordered on the South by the Gulf of Mexico, the west and north by Alabama, and on the east by Santa Rosa County. The distance from the Gulf of Mexico to the southern border of Alabama is approximately 50 miles (Escambia County, 2005). The County encompasses 663.6 square miles, with 451 persons per square mile. Escambia County is the $13^{\text {th }}$ densest state within Florida.

Population and Demographics

In 2000, Escambia County was the $15^{\text {th }}$ most populous County in the state with 294,410 residents. The City of Pensacola and Century are the only two municipalities within the county. The unincorporated area has the greatest population with 236,441 residents, followed by Pensacola $(56,255)$ and Century $(1,714)$ (BEBR, 2003).

In 2000, 294,410 people lived in the County, an increase of 12.0 percent since the 1990 Census (262,798 persons). This is smaller than the percent change for the state of Florida (23.5 percent). Estimates based upon the U.S. Census show a 1.72 percent change in the population between 2000 and 2002, which is 2.61 percent smaller than the state (BEBR, 2003). Population projections for the County show the population to increase to 319,700 by 2010 and 344,500 by 2020 .

The median age of residents within Escambia County is younger than the state, with a value of 35.6 compared to 39.4 for Florida. The median age is projected to only increase to 36.9 by 2020 (BEBR, 2003). As seen in Table 10, approximately 40 percent of the population is 45 years of age and older. 
Table 10. 2002 Estimates of Persons by Age Group in Escambia County

\begin{tabular}{|l|c|c|}
\hline Age & Population & Percent \\
\hline $\mathbf{0 - 1 4}$ & 57,996 & 19.4 \\
\hline $\mathbf{1 5 - 2 4}$ & 47,440 & 15.8 \\
\hline $\mathbf{2 5 - 4 4}$ & 85,579 & 28.6 \\
\hline $\mathbf{4 5 - 6 4}$ & 68,438 & 22.9 \\
\hline $\mathbf{6 5}$ and over & 40,032 & 13.4 \\
\hline Total & 299,485 & 100.0 \\
\hline
\end{tabular}

*Source: Bureau of Business and Economic Research, 2003

The percentage of residents in the County aged 65 and older is only 13 percent. Over 50 percent of persons aged 65 and older are between the ages of 65 and 74 (see Table 11.), while 11.3 percent are aged 85 and older.

Table 11. Persons Aged 65 and Older Population and Projections in Escambia County

\begin{tabular}{|l|c|c|c|c|c|c|}
\hline Age & $\begin{array}{c}\text { Population } \\
\text { 2002 }\end{array}$ & Percent & $\begin{array}{c}\text { Projections } \\
\text { 2010 }\end{array}$ & Percent & $\begin{array}{c}\text { Projections } \\
\mathbf{2 0 2 5}\end{array}$ & Percent \\
\hline $\mathbf{6 5 - 7 4}$ & 21,338 & 53.3 & 22,994 & 52.0 & 35,396 & 55.4 \\
\hline $\mathbf{7 5 - 8 4}$ & 14,165 & 35.4 & 15,015 & 34.0 & 20,444 & 32.0 \\
\hline $\mathbf{8 5}$ and over & 4,529 & 11.3 & 6,204 & 14.0 & 8,034 & 12.6 \\
\hline Total & 40,032 & 100 & 44,213 & 100 & 63,874 & 100 \\
\hline
\end{tabular}

*Source: Bureau of Business and Economic Research, 2003

Public Transportation

Escambia County Area Transit is a department within the county government. The Board of County Commissioners, which consists of five elected officials, serves as the governing board for ECAT. The service area population density was 1,840 persons per square mile in 2002. Both fixed-route motorbus and demand-response transportation services are provided by ECAT. The weekday span of service offered by ECAT is 15.5 hours. In 2003, there were 1,271,425 total annual riders of the fixed-route system. 


\section{Paratransit Services}

ECAT has 1,504 total certified ADA users (2004), 695 (5 percent) of which access fixed route services as well. The rest solely access paratransit services. There are 110 certified ADA users who do not currently live within the service area.

Table 12. Paratransit Ridership Data, ECAT

\begin{tabular}{|c|c|}
\hline Year & \# of Certified ADA Users \\
\hline 2000 & Compiled monthly \\
\hline 2001 & Compiled monthly \\
\hline 2002 & Compiled monthly \\
\hline 2003 & 1,135 \\
\hline
\end{tabular}

Table 13. Number of Paratransit Trips Made per Year, ECAT

\begin{tabular}{|c|c|}
\hline Year & \# ADA Trips/Year \\
\hline 2000 & 57,641 \\
\hline 2001 & 51,585 \\
\hline 2002 & 53,614 \\
\hline 2003 & 58,943 \\
\hline 2004 & 43,839 YTD \\
\hline \multicolumn{2}{|c|}{ Source: CUTR Survey } \\
\hline
\end{tabular}

To determine ADA eligibility, ECAT uses the following criteria. Applicants are individually evaluated and eligibility is determined based on a functional ability to use conventional public transportation. Categories 1, 2, and 3 of the Americans with Disabilities Act are used to determine functional inability to use public transportation. These three categories that individuals are placed as are 1) an individual has a temporary or permanent disability that prevents them from using the fixed bus route service, 2) individual needs the assistance of a wheelchair lift or other boarding assistance device, and is able, with such assistance, to board, ride, and disembark from accessible transit vehicles, or 3) individual has a specific impairment-related condition which prevents the individual from traveling to or from ECAT stations/stops.

The fare per ADA trip is $\$ 3.00$, with an actual cost per ADA paratransit trip of $\$ 16.19$. The fare for the fixed-route system is $\$ 1.50$. ADA paratransit services are offered during the same hours that fixed-route services are offered, except in commuter route areas. ADA paratransit services are contracted out to Pensacola Bay Transportation. 
Table 14. Costs of Operating ADA Paratransit Service, ECAT

\begin{tabular}{|c|c|c|c|c|}
\hline Year & $\begin{array}{c}\text { Contractor } \\
\text { name or in- } \\
\text { house }\end{array}$ & $\begin{array}{c}\text { Maintenance } \\
\text { Costs }\end{array}$ & $\begin{array}{c}\text { Operation } \\
\text { Costs }\end{array}$ & Cost/Trip \\
\hline $\mathbf{2 0 0 0}$ & Tucker & $\$ 75,935$ & $\$ 483,916$ & $\$ 11.98$ \\
\hline $\mathbf{2 0 0 1}$ & ATC & $\$ 90,378$ & $\$ 582,910$ & $\$ 15.81$ \\
\hline $\mathbf{2 0 0 2}$ & ATC & $\$ 107,814$ & $\$ 877,826$ & $\$ 19.23$ \\
\hline $\mathbf{2 0 0 3}$ & ATC & $\$ 98,801$ & $\$ 734,375$ & $\$ 17.61$ \\
\hline \multicolumn{4}{|c|}{ Source: CUTR Survey } \\
\hline
\end{tabular}

Methodology for Forecasting Paratransit Demand

To forecast ADA paratransit ridership, ECAT compares the total number of completed trips from year to year to compute the average growth increase.

Table 15. Forecasted Values for ADA Ridership, ECAT

\begin{tabular}{|l|l|l|}
\hline Year & $\begin{array}{l}\text { Estimated ADA Paratransit } \\
\text { Ridership }\end{array}$ & $\begin{array}{l}\text { Methodology Used to Determine } \\
\text { Number }\end{array}$ \\
\hline 2004 & N/A & $9 \%$ increase per the methodology \\
\hline
\end{tabular}

Source: CUTR Survey 


\section{King County, Washington}

Population and Demographics

The U.S. Census Bureau estimates the population of King County, Washington at 1,761,411 which is approximately 29 percent of the state of Washington. There are 817 persons per square mile, and a total of 2,126 square miles within the county. Since 1990, the population of the county has increased 15.2 percent. Estimates based upon the U.S. Census show a small population change of 1.4 percent between 2000 and 2003 (U.S. Census Bureau, 2005). King County has a relatively small population of persons 65 and older (10.5 percent).

Public Transportation

Metro Transit serves King County, offering a variety of transportation services, including fixed-route motorbus, paratransit, and a vanpool program. Metro Transit provides service to 100 million riders a year.

\section{Paratransit Services}

King County Metro had approximately 96,186,372 passenger boardings in 2003 (the number of unique individuals is not available). There are 1041 certified ADA users who live outside of their service area, which represents 3.8 percent of the total certified. If these individuals can get to an address within the service area, service is still provided.

Table 16. Paratransit Ridership Data, King County

\begin{tabular}{|c|c|}
\hline Year & \# of Certified ADA Users \\
\hline 2000 & 26,251 \\
\hline 2001 & 25,848 \\
\hline 2002 & 27,016 \\
\hline 2003 & 27,267 \\
\hline \multicolumn{2}{|c|}{ Source: CUTR Survey } \\
\hline
\end{tabular}


Table 17. Number of Paratransit Trips Made per Year, King County

\begin{tabular}{|c|c|}
\hline Year & \# ADA Trips/Year \\
\hline 2000 & 998,624 \\
\hline 2001 & 976,707 \\
\hline 2002 & 991,464 \\
\hline 2003 & $1,024,491$ \\
\hline 2004 & 706,543 YTD \\
\hline \multicolumn{2}{|c|}{ Source: CUTR Survey }
\end{tabular}

To determine ADA eligibility, King County Metro uses the following process. A person contacts their office and is sent a pre-application that describes ADA paratransit and asks three basic questions about the applicant's ability to use fixed route services. With the application, information is included about public transportation alternatives to paratransit. If the pre-application is returned, a regular application will then be mailed to them. There are separate forms for a personal care attendant, door to door service, or hand to hand service if the applicant has indicated a need for these services on the pre-application.

The fare for ADA riders is $\$ 0.75$ each way, while the actual cost per trip is approximately $\$ 30.62$. Regular adult fares for fixed-route service range from $\$ 1.25$ off peak, to $\$ 2.00$ for two-zone peak. Disabled and senior riders pay $\$ 0.25$ off peak and $\$ 0.50$ peak. ADA paratransit services are offered at the same hours as fixed-route service. ADA paratransit services are contracted out, but King County purchases and owns the fleet. ADA paratransit operations are contracted out to ATC Vancom, MV Public Transportation, and Seattle Personal Transit. Reservations, scheduling, and dispatch services are contracted out to Laidlaw Transit Services. 
Table 18. Costs of Operating ADA Paratransit Service, King County

\begin{tabular}{|c|c|c|c|c|}
\hline Year & $\begin{array}{c}\text { Contractor } \\
\text { name }\end{array}$ & $\begin{array}{c}\text { Maintenance } \\
\text { Costs }\end{array}$ & $\begin{array}{c}\begin{array}{c}\text { Operation } \\
\text { Costs }\end{array} \\
\end{array}$ & Cost/Trip \\
\hline 2000 & $\begin{array}{l}\text { Different } \\
\text { contracts } \\
\text { than 2001-04 }\end{array}$ & NA & NA & $\$ 28.40$ average \\
\hline 2001 & $\begin{array}{l}\text { ATC } \\
\text { MV } \\
\text { SPT } \\
\text { LTS }\end{array}$ & NA & NA & $\begin{array}{l}\text { \$26.78 (inc. fuel) } \\
\$ 27.61 \text { (inc. fuel) } \\
\text { \$23.13 (inc. fuel) } \\
\text { \$5.58 } \\
\text { All rates include } \\
\text { start up expenses }\end{array}$ \\
\hline 2001 & $\begin{array}{l}\text { ATC } \\
\text { MV } \\
\text { SPT } \\
\text { LTS }\end{array}$ & NA & NA & $\begin{array}{l}\$ 27.86 \text { (inc. fuel) } \\
\$ 26.40 \text { (inc. fuel) } \\
\$ 21.70 \text { (inc. fuel) } \\
\$ 4.42\end{array}$ \\
\hline 2001 & $\begin{array}{l}\text { ATC } \\
\text { MV } \\
\text { SPT } \\
\text { LTS }\end{array}$ & NA & NA & $\begin{array}{l}\$ 27.02 \\
\$ 25.03 \\
\$ 20.92 \\
\$ 5.27\end{array}$ \\
\hline
\end{tabular}

Methodology for Forecasting Paratransit Demand

To forecast ADA paratransit ridership, King County uses a "homegrown" spreadsheet to forecast demand and associated expenses. There are seven factors that are considered to impact paratransit demand and are analyzed yearly for the upcoming service year. Five of these factors are: fare increases, percentage of zero trip denials, the implementation of conditional eligibility, mirroring of fixed-route service, and the implementation of curb to curb service. These five factors have the greatest effect on obtained values for forecasted demand. The additional two factors, the introduction of early service, and changes to the population of individuals that were grandfathered in before service areas were designated, are also considered, but their effect may be minimal. Changes within these factors result in a value (as a percentage) being applied to the particular factor. If no changes are to occur for the upcoming year of service for a particular factor, then a " 0 " is entered in the spreadsheet for this category. Other values that are applied are determined based on an educated knowledge of the system, service area, and needs. The largest percent changes that may be assigned for a particular factor is generally no greater than five to six percent. Each of these values is applied to the previous year's actual data to formulate the 
projections. Census information for population and demographic changes are also considered during the forecasting process as well.

Table 19. Forecasted Values for ADA Ridership, King County

\begin{tabular}{|l|l|l|}
\hline Year & $\begin{array}{l}\text { Estimated ADA Paratransit } \\
\text { Ridership }\end{array}$ & $\begin{array}{l}\text { Methodology Used to Determine } \\
\text { Number }\end{array}$ \\
\hline 2000 & $1,029,592$ & See above \\
\hline 2001 & 969,997 & See above \\
\hline 2002 & 956,803 & See above \\
\hline 2003 & $1,004,556$ & See above \\
\hline 2004 & $1,072,928$ & See above \\
\hline
\end{tabular}

Source: CUTR Surveys 


\section{Manatee County}

Location

Manatee County is located on the west coast of Florida and occupies a land area of just over 740 square miles including 150 miles of coastline and 27 miles of beaches. Manatee County is surrounded by Hillsborough County to the north, Sarasota County to the south, Hardee and DeSoto Counties to the east, and the Gulf of Mexico to the west.

Population and Demographics

According to the 2000 U.S. Census, 264,002 people reside in the County, an increase of $24.7 \%$ since the 1990 Census (211,707 persons). This growth was greater than that experienced by the state (23.5 percent). Manatee County is the $15^{\text {th }}$ densest county in the state with 374 persons per square mile (BEBR 2003). There are six municipalities in the county with the largest populations belonging to Bradenton $(49,504)$ and Palmetto $(12,571)$ (BEBR, 2003). The Cities of Longboat Key, Anna Maria, Holmes Beach and Bradenton Beach comprise the remaining incorporated area, situated on the barrier islands just off the Gulf of Mexico.

Estimates based upon the U.S. Census show a 5.06 percent change in the population between 2000 and 2002 (BEBR, 2003). Population projections for the County show the population to increase to 318,300 by 2010 and 368,700 by 2020 .

The median age of residents within Manatee County is 44.6 compared to the median age of 39.4 for the state of Florida. The median age is projected to increase to 52.1 by 2020 (BEBR, 2003). As illustrated in Table 20., the age category with the largest population is 65 and over (24.8 percent).

Table 20. 2002 Estimates of Persons by Age Group in Manatee County

\begin{tabular}{|l|c|c|}
\hline Age & Population & Percent \\
\hline $\mathbf{0 - 1 4}$ & 47,050 & 17.0 \\
\hline $\mathbf{1 5 - 2 4}$ & 27,976 & 10.1 \\
\hline $\mathbf{2 5 - 4 4}$ & 65,066 & 23.5 \\
\hline $\mathbf{4 5 - 6 4}$ & 68,455 & 24.7 \\
\hline 65 and over & 68,815 & 24.8 \\
\hline Total & 277,362 & 100.0 \\
\hline
\end{tabular}

*Source: Bureau of Business and Economic Research, 2003 
As shown in Table 21., approximately half of persons over 65 are between the ages of 65 and 74 (48.9 percent). Approximately 40 percent of those above the age 65 are between the ages of 75 and 84 .

Table 21. Persons Aged 65 and Older Population and Projections in Manatee County

\begin{tabular}{|l|c|c|c|c|c|c|}
\hline Age & $\begin{array}{c}\text { Population } \\
\mathbf{2 0 0 2}\end{array}$ & Percent & $\begin{array}{c}\text { Projections } \\
\mathbf{2 0 1 0}\end{array}$ & Percent & $\begin{array}{c}\text { Projections } \\
\mathbf{2 0 2 5}\end{array}$ & Percent \\
\hline $\mathbf{6 5 - 7 4}$ & 33,662 & 48.9 & 40,291 & 49.6 & 71,352 & 53.6 \\
\hline $\mathbf{7 5 - 8 4}$ & 26,522 & 38.5 & 28,605 & 35.2 & 45,125 & 33.9 \\
\hline $\mathbf{8 5}$ and over & 8,631 & 12.5 & 12,330 & 15.2 & 16,759 & 12.6 \\
\hline Total & 68,815 & 100 & 81,226 & 100 & 133,236 & 100 \\
\hline
\end{tabular}

*Source: Bureau of Business and Economic Research, 2003

Public Transportation

Manatee County Area Transit (MCAT) is a division within the Community Services Department of Manatee County. The division is governed by the Board of County Commissioners. Transit service is provided to the urbanized areas of the county in the form of fixed-route motorbus, demand-response, and vanpools. The service area population for Manatee County is 278,144 , with a density of 1,030 per square mile. The weekday span of service is 13 hours.

\section{Paratransit Services}

MCAT has 190 certified ADA users in their service area, with seven users also accessing fixed route services and 183 only using paratransit services. There are 19 ADA users who do not currently live within the service area. There are approximately 850,000 total riders of the fixed route system.

Table 22. Paratransit Ridership Data, MCAT

\begin{tabular}{|c|c|}
\hline Year & \# of Certified ADA Users \\
\hline 2000 & 213 \\
\hline 2001 & 183 \\
\hline 2002 & 157 \\
\hline 2003 & 190 \\
\hline \multicolumn{2}{|c|}{ Source: CUTR Survey }
\end{tabular}


Table 23. Number of Paratransit Trips Made per Year, MCAT

\begin{tabular}{|c|c|}
\hline Year & \# ADA Trips/Year \\
\hline 2000 & 8,443 \\
\hline 2001 & 8,324 \\
\hline 2002 & 6,750 \\
\hline 2003 & 6,784 \\
\hline 2004 & 5,379 (as of 09/12/04) \\
\hline
\end{tabular}

To determine ADA eligibility, Manatee County uses the following process. The client is mailed an application and then has an interview with the Manasota Association for Retarded Citizens, who determine eligibility.

The fare per ADA trip is $\$ 2.00$, while the actual cost per ADA trip is $\$ 15.27$. The fare for the fixed-route service is $\$ 1.00$. ADA transit services are provided in-house. The fleet consists of 28 vehicles, with an average age of 4.5 years, and an average cost of $\$ 54,489$.

Table 24. Costs of Operating ADA Paratransit Service, MCAT

\begin{tabular}{|c|c|c|c|c|}
\hline Year & $\begin{array}{c}\text { Contractor } \\
\text { name or in- } \\
\text { house }\end{array}$ & $\begin{array}{c}\text { Maintenance } \\
\text { Costs }\end{array}$ & $\begin{array}{c}\text { Operation } \\
\text { Costs }\end{array}$ & Cost/Trip \\
\hline $\mathbf{2 0 0 0}$ & In-house & $\$ 169,485$ & $\$ 117,358$ & $\$ 13.90$ \\
\hline $\mathbf{2 0 0 1}$ & In-house & $\$ 186,538$ & $\$ 96,322$ & $\$ 14.27$ \\
\hline $\mathbf{2 0 0 2}$ & In-house & $\$ 194,717$ & $\$ 93,623$ & $\$ 13.87$ \\
\hline $\mathbf{2 0 0 3}$ & In-house & $\$ 288,943$ & $\$ 103,592$ & $\$ 15.27$ \\
\hline \multicolumn{5}{|c|}{ Source: CUTR Survey } \\
\hline
\end{tabular}

Methodology for Forecasting Paratransit Demand

To forecast ADA paratransit ridership, Manatee County looks at ADA ridership trends over several years. Close attention is paid to increases and decreases in ridership, some averaging is done and ridership is predicted based on those figures. 


\section{New York City}

Population and Demographics

A combination of population estimates for Bronx, King, New York, Richmond and Queens Counties from the U.S. Census Bureau places the value at 8,085,742 persons. The densities among the three counties vary, with New York County having 66,940 persons per square mile to Richmond County only having 7,587.9 persons per square mile. The combined size of these five counties is 303 square miles. The average percentage of persons aged 65 and older is 11.6 percent.

Public Transportation

New York City Transit is the largest agency in the Metropolitan Transportation Authority (MTA) regional transportation network. Other services provided by MTA include the Staten Island Railway, MTA Long Island Bus, MTA Metro-North Railroad, MTA Bridges and Tunnels, and MTA Capital Construction. There are more buses in MTA than any other system in North America, and services are provided 24 hours a day throughout the five boroughs. Approximately seven million people use NYC Transit each day.

\section{Paratransit Services}

New York City Transit has 80,647 certified ADA users in their area as of December 2003, with 34,034 conditionally eligible customers that also access fixed route services. There were 735.4 million fixed-route passenger boardings in 2003. There are 302 certified ADA users who did not live in the service area ( 0.4 percent), as of December 2003.

Table 25. Paratransit Ridership Data, NYC Transit

\begin{tabular}{|c|c|}
\hline Year & \# of Certified ADA Users \\
\hline 2000 & 59,721 \\
\hline 2001 & 64,902 \\
\hline 2002 & 73,411 \\
\hline 2003 & 80,647 \\
\hline \multicolumn{2}{|c|}{ Source: CUTR Survey }
\end{tabular}


Table 26. Number of Paratransit Trips Made per Year, NYC Transit

\begin{tabular}{|c|c|}
\hline Year & \# ADA Trips/Year \\
\hline 2000 & $1,696,269$ \\
\hline 2001 & $2,017,217$ \\
\hline 2002 & $2,227,702$ \\
\hline 2003 & $2,576,302$ \\
\hline 2004 & $1,607,673(7 / 04)$ \\
\hline \multicolumn{2}{|c|}{ Source: CUTR Survey }
\end{tabular}

To determine ADA eligibility, NYC Transit uses the following process. First the application is received, and then the information is entered and submitted to a certifier for review. At this point, the certifier may evaluate the application and determine the eligibility status, or they determine that a further assessment must be conducted through either an interview or in-person assessment.

The fare per ADA trip is \$2.00, while the actual cost per trip is \$55.99. The fare for the fixed route service is also $\$ 2.00$. ADA paratransit services and fixed-route services are both offered 24 hours a day, 7 days a week. Transportation for the ADA service is contracted out; however NYC Transit purchases the vehicles. The fleet consists of approximately 967 vehicles (as of 12/31/03), with a median age of 3 years. The average cost per vehicle ranges from $\$ 21,088$ to $\$ 50,408$ depending on the type of vehicle. There are 97 mechanics working on the fleet.

\section{Methodology for Forecasting Paratransit Demand}

A specific methodology is not utilized by New York City Transit to forecast paratransit demand. An evaluation of historical data provides the agency with the number needed to plan for future demand for service. The historical data consists of ridership trends recorded by the agency. The information is evaluated every year as part of the budgeting process. 


\section{Orange County, CA}

Population and Demographics

The U.S. Census Bureau estimates the population of Orange County at 2,957,766, which is approximately eight percent of the state of California. There are 3,605 persons per square mile which is considerably greater than the state of California with only 217.2 persons per square mile. The size of the county is 759 square miles. Since 1990, the population of the county has increased 18.1 percent. Estimates based upon the U.S. Census show a 3.9 percent change in the population between 2000 and 2003 (U.S. Census Bureau, 2005). Orange County has a relatively small population of persons 65 and older (9.9 percent). 27 percent of persons are under the age of 18.

Public Transportation

The Orange County Transportation Authority (OCTA) is the primary provider of transportation services within the county. OCTA provides bus and paratransit service, as well as commuter rail service, and is planning for a light rail system. A Board of Directors consists of 18 members and governs OCTA.

\section{Paratransit Services}

OCTA has 25, 584 certified ADA users in their service area, as of August 2004, with an unknown number accessing fixed route services. The percentage of certified users that use only paratransit service is unknown, as is the number of users that do not live in the service area.

Table 27. Paratransit Ridership Data, OCTA

\begin{tabular}{|c|c|}
\hline Year & \# of Certified ADA Users \\
\hline 2000 & 10,000 EST \\
\hline 2001 & 12,000 \\
\hline 2002 & 16,000 \\
\hline 2003 & 21,000 \\
\hline
\end{tabular}


Table 28. Number of Paratransit Trips Made per Year, OCTA

\begin{tabular}{|c|c|}
\hline Year & \# ADA Trips/Year \\
\hline 2000 & 665,664 EST \\
\hline 2001 & 692,733 \\
\hline 2002 & 779,298 \\
\hline 2003 & 909,146 \\
\hline 2004 & $1,085,329$ YTD \\
\hline \multicolumn{2}{|c|}{ Source: CUTR Survey } \\
\hline
\end{tabular}

To determine ADA eligibility, OCTA uses the following process. First, an application must be requested by those seeking eligibility. Following its submittal, an assessment of the applicant is completed. This is accomplished by either review of the application, an in-person interview, or a functional assessment. After the assessment is complete a determination is made.

The fare per ADA trip is $\$ 2.00, \$ 0.30$ of which is paid by local transportation funds, so the cost to the user is $\$ 1.70$, while the actual trip cost is approximately $\$ 27.00$. The fare for the fixed-route system is $\$ 1.00$. ADA paratransit services are contracted out to Laidlaw Transportation Services, Inc. ADA paratransit service and fixed-route service operates 24 hours a day.

\section{Methodology for Forecasting Paratransit Demand}

A consultant study done in 2003 is used to forecast ADA paratransit ridership. This study developed a time series model to forecast the demand. An objective of the development of the model was to assist the agency in meeting its zero trip denial policy and to also forecast demand beyond the scope of one year. The consultants were contracted to complete this task by evaluating ridership over a five year period. In order to develop the model, an analysis of archived data of 1.8 million daily boardings over a 34-month period was conducted and other factors were considered as well. The model predicts OCTA's daily ADA one-way passenger boardings. These values can be amassed to generate ridership for larger units, such as monthly and yearly. It was determined that the model must be based upon predictor variables that exhibit a significant relationship to ADA demand, and that the model should be flexible in its ability to respond to changes in factors that influence demand. 
Efforts to develop the model included an extensive analysis of historical data. Four indepth analyses of data recorded in Trapeze were conducted. This included the identification of the following:

- time-related demand patterns by time-of-day, day of the week and month

- passenger characteristics including age and disability

- geographic distributions by zip code, city, and north and south areas

- trip characteristics including trip frequency, purpose, and distance.

Additional factors were considered including an individuals' eligibility and scheduled versus actual trips. Following the collection of the above mentioned data, a comparison between 2000 census data of the County's cities or designated places and the gathered data was completed. The Census variables analyzed included age, seniors in poverty, number of disabled persons, and the rate of ADA certified riders by city. One final analysis of Trapeze data compared the information with other data sources, such as contractor dispatch logs and invoicing records.

An effort to involve the community was also made during the development of the model. Qualitative factors and programs that could have an effect on ADA demand were discussed with the public. Public input was targeted through discussions with long-term care facilities, hospitals and acute care settings, programs serving persons with developmental disabilities, senior services, and disability programs for children and youth.

A third factor that was considered for the development of the model was the results of a peer review. A review of 48 transit providers, including other large agencies and other California transit agencies, was conducted to understand processes and information associated with each. Data regarding total service area population, the number of active vehicles, the number of certified ADA users, service area square mileage, and any available information for methodologies used to forecast demand was gathered.

Once efforts to conduct research through the previously mentioned methods were complete, it was determined that data gathered through the Trapeze system was not a reliable source for use in the model, the reason being that significant gaps in the data existed, and changes in data collection had occurred during the time frame in which data was to be used. It was then determined that information gathered and collected by the 
contractor for paratransit services would be used in place of that previously provided by Trapeze.

Ultimately, the model used historical data of daily passenger boardings over a two year time period. The model is based upon a multi-variable regression analysis that incorporates information of recent ridership trends, historical growth trends, the time of year, day of the week, and holidays. The model was also developed to consider changes in many variables that may affect ADA demand. The table below shows the value forecasted for paratransit demand for the year 2004.

Table 29. Forecasted Values for ADA Ridership, OCTA

\begin{tabular}{|l|l|l|}
\hline Year & $\begin{array}{l}\text { Estimated ADA Paratransit } \\
\text { Ridership }\end{array}$ & $\begin{array}{l}\text { Methodology Used to Determine } \\
\text { Number }\end{array}$ \\
\hline 2000 & N/A & N/A \\
\hline 2001 & N/A & N/A \\
\hline 2002 & N/A & N/A \\
\hline 2003 & N/A & N/A \\
\hline 2004 & $1,060,101$ & Consultant study/model \\
\hline
\end{tabular}

Source: CUTR Survey 


\section{Pasco County}

Location

Located on the Gulf of Mexico in the Tampa Bay area, Pasco is part of a nine-county region referred to as the "Nature Coast." The county is bordered by Hillsborough and Pinellas counties to the south, Hernando County to the north, Polk and Sumter counties to the east, and the Gulf of Mexico to the west. There are 745 square miles in the county.

Population and Demographics

Pasco County is the $13^{\text {th }}$ most populous county in Florida, with a population of 361,468 (BEBR, 2003). There are 485 persons per square mile. Six municipalities are located within the county with the largest populations residing in New Port Richey $(16,117)$ and Zephyrhills (10,833). Approximately 90 percent of residents live in the unincorporated area of the county (BEBR, 2003). Since 1990, the population of the county has increased 22.6 percent. Estimates based upon the U.S. Census show a 4.84 percent change in the population between 2000 and 2002 (BEBR, 2003).

The median age of residents within Pinellas County is 46.3 compared to the median age of 39.4 for the state of Florida. The median age is projected to increase to 56.5 by 2020 (BEBR, 2003). As shown in Table 30., the largest proportion of the population is in the category of persons aged 65 and older (27 percent).

Table 30. 2002 Estimates of Persons by Age Group in Pasco County

\begin{tabular}{|l|c|c|}
\hline Age & Population & Percent \\
\hline $\mathbf{0 - 1 4}$ & 58,701 & 16.2 \\
\hline $\mathbf{1 5 - 2 4}$ & 34,627 & 9.6 \\
\hline $\mathbf{2 5 - 4 4}$ & 81,422 & 22.5 \\
\hline $\mathbf{4 5 - 6 4}$ & 89,114 & 24.7 \\
\hline 65 and over & 97,604 & 27.0 \\
\hline Total & 361,468 & 100.0 \\
\hline
\end{tabular}

*Source: Bureau of Business and Economic Research, 2003

As shown in Table 31., approximately half of persons over 65 are between the ages of 65 and 74 (47.8 percent). The number of persons in this category is expected to increase to 50.4 percent by 2010 . 
Table 31. Persons Aged 65 and Older Population and Projections in Pasco County

\begin{tabular}{|l|c|c|c|c|c|c|}
\hline Age & $\begin{array}{c}\text { Population } \\
\mathbf{2 0 0 2}\end{array}$ & Percent & $\begin{array}{c}\text { Projections } \\
\mathbf{2 0 1 0}\end{array}$ & Percent & $\begin{array}{c}\text { Projections } \\
\mathbf{2 0 2 5}\end{array}$ & Percent \\
\hline $\mathbf{6 5 - 7 4}$ & 46,622 & 47.8 & 59,760 & 50.4 & 105,592 & 52.9 \\
\hline $\mathbf{7 5 - 8 4}$ & 39,041 & 40.0 & 42,383 & 35.7 & 71,407 & 35.8 \\
\hline $\mathbf{8 5}$ and over & 11,941 & 12.2 & 16,535 & 13.9 & 22,486 & 11.3 \\
\hline Total & 97,604 & 100 & 118,678 & 100 & 199,485 & 100 \\
\hline
\end{tabular}

*Source: Bureau of Business and Economic Research, 2003

Public Transportation

Pasco County Public Transportation (PCPT) is a division of Pasco County Government which is directed by the Pasco County Commission that is comprised of five members. Fixed-route services are provided in the urbanized area of west Pasco County and in the municipalities in east Pasco County. Demand-response service is available throughout the county. During FY 2002, the service area population of PCPT was 362,658 and service area population density was 486 persons per square mile. The weekday span of service was 14.5 hours.

Paratransit Services

In 2003, Pasco County Public Transportation (PCPT) recorded 827 certified ADA users of their system.

Table 32. Paratransit Ridership Data, PCPT

\begin{tabular}{|c|c|}
\hline Year & \# of Certified ADA Users \\
\hline 2003 & 827 \\
\hline \multicolumn{2}{c}{ Source: CUTR Survey }
\end{tabular}

To determine ADA eligibility, PCPT uses the following process. The application is requested and submitted to PCPT. If the applicant lives within $3 / 4$ mile of a fixed-route and they are unable to use the system because of a disability, they may be considered eligible for ADA services. Once eligible, a request for a trip is determined dependent upon their origin and destination and the requested time. The fare per ADA trip is $\$ 2.00$, while the fare for the fixed-route system is $\$ 1.00$. ADA and fixed-route services are offered during the same hours and coverage. 
Methodology for Forecasting Paratransit Demand

No specific methodology is recorded by PCPT for forecasting paratransit demand in their service area. It is noted, however, that as service areas increase there are a number of factors that are evaluated. These factors include information regarding the area population, income levels of particular areas, and demographic information such as age. 


\section{Pinellas County, Florida}

\section{Location}

Pinellas County is a 38 mile long peninsula bordered by the Gulf of Mexico on the west, Tampa Bay to the east and south, and Pasco County to the north. The county is 280 square miles (U.S. Census Bureau, 2000) and only 15 miles wide at its greatest east-west point. Regardless of its relatively small size, the County is the sixth most populous in the state, and is the most densely populated by developable area, with 3,334 persons per square mile (BEBR, 2003).

Population and Demographics

Pinellas County has the greatest density of the state with 3,334 persons per square mile compared to a state average of only 309 (BEBR 2003). There are 24 municipalities in the county and 25 recognized local governments including the unincorporated area of the county. The largest cities are St. Petersburg $(248,232)$ and Clearwater $(108,789)$, followed by Largo $(69,371)$ and Pinellas Park $(45,658)$ (BEBR, 2003).

According to the 2000 U.S. Census, 921,495 people reside in the County, showing a growth of 8.2 percent since the 1990 Census (851,659 persons). Estimates based upon the U.S. Census show a 1.36 percent change in the population between 2000 and 2002 (BEBR, 2003).

The median age of residents within Pinellas County is 43.9 compared to the median age of 39.4 for the state of Florida. The median age is projected to increase to 49.9 by 2020 (BEBR, 2003). As seen in Table 33., approximately half (48 percent) of the population is 45 years of age and older.

Table 33. 2002 Estimates of Persons by Age Group in Pinellas County

\begin{tabular}{|l|c|c|}
\hline Age & Population & Percent \\
\hline $\mathbf{0 - 1 4}$ & 146,939 & 15.7 \\
\hline $\mathbf{1 5 - 2 4}$ & 93,455 & 10.0 \\
\hline $\mathbf{2 5 - 4 4}$ & 243,324 & 26.1 \\
\hline $\mathbf{4 5 - 6 4}$ & 242,049 & 25.9 \\
\hline $\mathbf{6 5}$ and over & 208,227 & 22.3 \\
\hline Total & 933,994 & 100.0 \\
\hline
\end{tabular}

*Source: Bureau of Business and Economic Research, 2003 
The percentage of residents in the County aged 65 and older is 22.3 percent. As shown in Table 34., approximately half of persons over 65 are between the ages of 65 and 74 (46.1 percent).

Table 34. Persons Aged 65 and Older Population and Projections in Pinellas County

\begin{tabular}{|l|c|c|c|c|c|c|}
\hline Age & $\begin{array}{c}\text { Population } \\
\text { 2002 }\end{array}$ & Percent & $\begin{array}{c}\text { Projections } \\
\mathbf{2 0 1 0}\end{array}$ & Percent & $\begin{array}{c}\text { Projections } \\
\mathbf{2 0 2 5}\end{array}$ & Percent \\
\hline $\mathbf{6 5 - 7 4}$ & 95,971 & 46.1 & 109,329 & 49.3 & 177,444 & 54.4 \\
\hline $\mathbf{7 5 - 8 4}$ & 80,342 & 38.6 & 75,887 & 34.2 & 109,091 & 33.5 \\
\hline $\mathbf{8 5}$ and over & 31,914 & 15.3 & 36,510 & 16.5 & 39,355 & 12.1 \\
\hline Total & 208,227 & 100 & 221,726 & 100 & 325,890 & 100 \\
\hline
\end{tabular}

*Source: Bureau of Business and Economic Research, 2003

Public Transportation

The Pinellas Suncoast Transit Authority (PSTA) is an independent body that is governed by a Board of Directors. Elected officials and private citizen appointees make up the Board. In 2002, PSTA's service area population was 862,076 and service area density was 4,124 persons per square mile. PSTA serves Pinellas County with the exception of Bellair Shores, Kenneth City, St. Pete Beach, and Treasure Island. Both fixed-route motorbus and demand-responsive service are provided by the authority. PSTA's weekday span of service is 20.6 hours.

Paratransit Services

PSTA has 11,286 certified ADA users in their service area, with 2 percent certified for "feeder" service (accessing fixed route service). There were approximately 10 million passenger boardings in fiscal year 2004. Approximately 98 percent of certified users access only paratransit services and only 0.2 percent currently do not live in the service area. 
Table 35. Number of Paratransit Trips Made per Year, PSTA

\begin{tabular}{|c|c|}
\hline Year & \# ADA Trips/Year \\
\hline 2000 & 249,437 \\
\hline 2001 & 242,068 \\
\hline 2002 & 239,777 \\
\hline 2003 & 242,383 \\
\hline 2004 & 259,000 estimated \\
\hline \multicolumn{2}{|c|}{ Source: CUTR Survey }
\end{tabular}

To determine ADA eligibility, PSTA uses a functional certification process to determine if a person has the ability to use the regular bus system. In-person assessments are utilized on an as-needed basis to facilitate the eligibility determination process.

The fare per ADA trip is $\$ 2.50$, while the actual cost per trip is approximately $\$ 17.46$ (excluding the fare portion). The fare for the fixed route system is \$1.25. PSTA utilizes a contract carrier, Transportation Contract Services, Inc., for all trips. Information about the fleet is unavailable. ADA paratransit services are offered during the same days and hours as the regular bus service for any given trip request. An ADA user may take a paratransit trip during the same hours that the fixed-route offers service to the same areas. Fixed-route services have not been cut in the past. However, a trend has been noted whereby demand response service follows the same trend as fixed route ridership.

Table 36. Costs of Operating ADA Paratransit Service, PSTA

\begin{tabular}{|l|c|c|c|}
\hline Year & $\begin{array}{l}\text { Contractor } \\
\text { name }\end{array}$ & $\begin{array}{l}\text { Operation } \\
\text { Costs }\end{array}$ & Cost/Trip \\
\hline $\mathbf{2 0 0 0}$ & TCSI & $\$ 3,394,065$ & $\$ 13.61$ \\
\hline $\mathbf{2 0 0 1}$ & TCSI & $\$ 3,664,119$ & $\$ 15.12$ \\
\hline $\mathbf{2 0 0 2}$ & TCSI & $\$ 3,808,034$ & $\$ 15.88$ \\
\hline $\mathbf{2 0 0 3}$ & TCSI & $\$ 4,089,596$ & $\$ 16.87$ \\
\hline \multicolumn{4}{|c|}{ Source: CUTR Survey } \\
\hline
\end{tabular}

Methodology for Forecasting Paratransit Demand

A specific methodology is not utilized by PSTA to forecast paratransit demand. An evaluation of historical data provides the agency with the number needed to plan for service for the upcoming budget year. The historical data, which is analyzed during the budget preparation process, consists of ridership trends experienced and recorded by the agency. 


\section{Polk County}

\section{Location}

Polk County is located in the center of the Florida peninsula, about equal distance from the east and west coast and half way between the Georgia-Florida border and the Southern tip of the peninsula. The county is located approximately 25 miles east of Tampa and 35 miles southwest of Orlando. The surrounding counties are Sumter and Lake Counties to the north, Hardee and Highlands Counties to the south, Osceola County to the east, and Hillsborough County to the west. The county is relatively large in size, with 1,874 square miles.

\section{Population and Demographics}

Polk County is less dense than the state of Florida with 268 persons per square mile compared to 309 (BEBR 2003). There are 17 municipalities in the county and 18 recognized local governments including the unincorporated county. The largest municipalities are Lakeland (78,452) and Winter Haven $(26,487)$ (BEBR, 2003). There are 302,797 persons residing in the unincorporated area.

According to the 2000 U.S. Census, 483,924 people reside in the County, showing a growth of 19.4 percent since the 1990 Census (405,382 persons). Estimates based upon the U.S. Census show a 3.81 percent change in the population between 2000 and 2002 (BEBR, 2003).

The median age of residents within Polk County is comparable with the state, with a value of 39.5 compared to 39.4 for Florida. The median age is projected to increase to 43.5 by 2020 (BEBR, 2003).

Table 37. 2002 Estimates of Persons by Age Group in Polk County

\begin{tabular}{|l|c|c|}
\hline Age & Population & Percent \\
\hline $\mathbf{0 - 1 4}$ & 99,554 & 19.8 \\
\hline $\mathbf{1 5 - 2 4}$ & 63,084 & 12.6 \\
\hline $\mathbf{2 5 - 4 4}$ & 127,189 & 25.3 \\
\hline $\mathbf{4 5 - 6 4}$ & 118,320 & 23.6 \\
\hline $\mathbf{6 5}$ and over & 94,238 & 18.8 \\
\hline Total & 502,385 & 100.0 \\
\hline
\end{tabular}

*Source: Bureau of Business and Economic Research, 2003 
As shown in Table 38., the majority of the population 65 years of age and older are between the ages of 65 and 74 (52.9 percent). This percentage is projected to remain relatively steady, with the value of 52.1 percent projected for 2010.

Table 38. Persons Aged 65 and Older Population and Projections in Polk County

\begin{tabular}{|l|c|c|c|c|c|c|}
\hline Age & $\begin{array}{c}\text { Population } \\
\mathbf{2 0 0 2}\end{array}$ & Percent & $\begin{array}{c}\text { Projections } \\
\mathbf{2 0 1 0}\end{array}$ & Percent & $\begin{array}{c}\text { Projections } \\
\mathbf{2 0 2 5}\end{array}$ & Percent \\
\hline $\mathbf{6 5 - 7 4}$ & 49,843 & 52.9 & 60,409 & 52.1 & 102,040 & 53.9 \\
\hline $\mathbf{7 5 - 8 4}$ & 34,027 & 36.1 & 39,306 & 33.9 & 62,842 & 33.2 \\
\hline $\mathbf{8 5}$ and over & 10,368 & 11.0 & 16,190 & 14.0 & 24,460 & 12.9 \\
\hline Total & 94,238 & 100 & 115,905 & 100 & 189,342 & 100 \\
\hline
\end{tabular}

*Source: Bureau of Business and Economic Research, 2003

\section{Public Transportation}

Polk County Intercity Transit is governed by the Polk County Board of County Commissioners. The system provides fixed-route bus and paratransit service throughout the county. Polk County Transit Services has also been contracted to provide fixed-route motorbus service in the City of Winter Haven (Winter Haven Area Transit). Operation in Winter Haven began in 1999. This system is governed by the WHAT Policy Board which is comprised of elected officials. The service area population of the Polk County Intercity Transit service was 86,427 during FY 2002. The service area population density was 3,201 persons per square mile. The weekday span of service offered by the system is 15 hours.

Paratransit Services

Polk County Intercity Transit has 2,560 certified ADA users in its service area, with 100 percent accessing only paratransit service. The number of certified ADA users that do not currently live in the service area is unknown. 
Table 39. Paratransit Ridership Data, Polk County Intercity Transit

\begin{tabular}{|l|l|}
\hline Year & \# of Certified ADA Users \\
\hline 2001 & 639 \\
\hline 2002 & 957 \\
\hline 2003 & 1009 \\
\hline 2004 & N/A \\
\hline \multicolumn{2}{|c|}{ Source: CUTR Survey }
\end{tabular}

To determine ADA eligibility, WHAT uses the following process: A paper application with medical certification is required. An additional in-person functional assessment may also be required before a determination is made.

The fare per ADA trip is $\$ 1.00$ and the fixed-route fare is $\$ 0.75$. ADA paratransit services are provided from the earliest fixed route start time through the latest route ending time. There was a reduction in the fixed-route service area, and a reduction in the frequency of service to one urbanized area due to low ridership. This allowed for service expansion into an area that did not have previously. The effects of this on ADA paratransit demand are yet to be determined.

\section{Methodology for Forecasting Paratransit Demand}

A particular method for forecasting demand has not yet been formulated by the agency. In order to plan for demands on the system, however, educated decisions based on historical data have been used. This data may include information such as ridership trends. 


\section{Regional Transit System - Alachua County}

Location

Alachua County is located in north central Florida. The counties surrounding Alachua include Marion, Levy, Putnam, Bradford, Union, Columbia, and Gilchrist. At the heart of Alachua County is the jurisdiction's largest city, Gainesville (population 98,245). The entire county ranks as the $20^{\text {th }}$ densest in the state of Florida with 261 persons per square mile.

Population and Demographics

According to the 2000 U.S. Census, 217,955 people reside in the County, showing a growth of 20.0 percent since the 1990 Census (181,596 persons). Estimates based upon the U.S. Census show a 4.89 percent change in the population between 2000 and 2002 (BEBR, 2003).

The median age of residents within Alachua County is younger than that of the state (29.0 compared to 39.4). The median age is expected to increase to only 29.9 by 2020 (BEBR, 2003). The University of Florida, which is located in Gainesville, has a significant impact on the demographics of the county and therefore results in the young median age. As seen in Table 40., more than half (70 percent) of the population is 45 years of age and younger. Only 9.6 percent of the county is aged 65 and older.

Table 40. 2002 Estimates of Persons by Age Group in Alachua County

\begin{tabular}{|l|c|c|}
\hline Age & Population & Percent \\
\hline $\mathbf{0 - 1 4}$ & 37,379 & 16.4 \\
\hline $\mathbf{1 5 - 2 4}$ & 61,675 & 27.0 \\
\hline $\mathbf{2 5 - 4 4}$ & 62,780 & 27.5 \\
\hline $\mathbf{4 5 - 6 4}$ & 44,857 & 19.6 \\
\hline $\mathbf{6 5}$ and over & 21,916 & 9.6 \\
\hline Total & 228,607 & 100.0 \\
\hline
\end{tabular}

*Source: Bureau of Business and Economic Research, 2003

As shown in Table 41., the largest percentage of those aged 65 and older are between the ages of 65 and 74 . The percentage within this age bracket is expected to increase to 49.1 percent by 2010 . 
Table 41. Persons Aged 65 and Older Population and Projections in Alachua County

\begin{tabular}{|l|c|c|c|c|c|c|}
\hline Age & $\begin{array}{c}\text { Population } \\
\mathbf{2 0 0 2}\end{array}$ & Percent & $\begin{array}{c}\text { Projections } \\
\mathbf{2 0 1 0}\end{array}$ & Percent & $\begin{array}{c}\text { Projections } \\
\mathbf{2 0 2 5}\end{array}$ & Percent \\
\hline $\mathbf{6 5 - 7 4}$ & 11,315 & 51.6 & 13,908 & 54.1 & 23,451 & 55.7 \\
\hline $\mathbf{7 5 - 8 4}$ & 7,859 & 35.9 & 8,175 & 31.8 & 13,837 & 32.9 \\
\hline $\mathbf{8 5}$ and over & 2,742 & 12.5 & 3,611 & 14.1 & 4,830 & 11.5 \\
\hline Total & 21,916 & 100 & 25,694 & 100 & 42,118 & 100 \\
\hline
\end{tabular}

*Source: Bureau of Business and Economic Research, 2003

Public Transportation

The Regional Transit System (RTS) is a department of the City of Gainesville. A commission, consisting of five elected members, governs RTS. RTS serves Gainesville and parts of Alachua County via fixed-route motorbus service. Demand response service is also provided by RTS to areas within $3 / 4$ mile of its fixed-route network. The service area population of RTS was 140,000 during FY 2002. During that time, the service area population density was 1,917 persons per square mile. The weekday span of service offered by RTS is 19.3 hours.

\section{Paratransit Services}

RTS has 2,262 certified ADA users in its service area, with approximately 35 percent of these users also accessing fixed route services. Of those 2,262 people, approximately 1,300 are determined fully eligible. The remaining certified users are considered conditionally eligible.

To determine ADA eligibility, RTS uses the following process. The client is interviewed by the Center for Independent Living where an assessment of the client's disability is made. The applicant must also receive professional verification of their eligibility for paratransit service through their health care provider. The applicant is then forwarded to RTS and a final decision is made regarding their status.

The fare per ADA trip is $\$ 2.00$ and ADA certified users receive free transportation on fixed-route service. ADA transit services are contracted out to different providers. The hours of ADA paratransit service vary dependent on the routes serving the area in which a trip is to be made. In general, however, the service runs from 6 am to $9 \mathrm{pm}$. 


\section{Methodology for Forecasting Paratransit Demand}

To forecast ADA paratransit ridership, RTS looks at ADA ridership trends over several years. Recent records indicate that the demand for ADA service has been forecasted at a 10 percent increase each year. 


\section{Sarasota County}

Location

Sarasota County is located on the southwest coast of Florida. It encompasses an area of about 571 square miles and is located 60 miles south of Tampa. The county is bordered by Manatee County to the north, DeSoto County to the east, Charlotte County to the south, and the Gulf of Mexico to the west.

Population and Demographics

The City of Sarasota (population 52,715) is the county seat. Other municipalities include the cities of Venice $(17,764)$, North Port $(22,797)$, and the Town of Longboat Key $(5,012)$. The county is the ninth densest in the state, with approximately 594 persons per square mile.

According to the 2000 U.S. Census, 325,957 people reside in the County, showing a growth of 17.3 percent since the 1990 Census (277,776 persons). Estimates based upon the U.S. Census show a 4.21 percent change in the population between 2000 and 2002 (BEBR, 2003).

The median age of residents within Sarasota County is older than that of the state (41.6 compared to 39.4). The median age is projected to increase to 59.0 by 2020 (BEBR, 2003). As seen in Table 42, more than half (58.4 percent) of the population is 45 years of age and older. The largest proportion of the county is aged 65 and older (31.4 percent).

Table 42. 2002 Estimates of Persons by Age Group in Sarasota County

\begin{tabular}{|l|c|c|}
\hline Age & Population & Percent \\
\hline $\mathbf{0 - 1 4}$ & 43,988 & 12.9 \\
\hline $\mathbf{1 5 - 2 4}$ & 27,681 & 8.1 \\
\hline $\mathbf{2 5 - 4 4}$ & 69,790 & 20.5 \\
\hline $\mathbf{4 5 - 6 4}$ & 91,563 & 27.0 \\
\hline $\mathbf{6 5}$ and over & 106,662 & 31.4 \\
\hline Total & 339,684 & 100.0 \\
\hline
\end{tabular}

*Source: Bureau of Business and Economic Research, 2003 
As shown in Table 43., the largest percentage of those aged 65 and older are between the ages of 65 and 74 . The percentage within this age bracket is expected to increase to 49.1 percent by 2010.

Table 43. Persons Aged 65 and Older Population and Projections in Sarasota County

\begin{tabular}{|l|c|c|c|c|c|c|}
\hline Age & $\begin{array}{c}\text { Population } \\
\mathbf{2 0 0 2}\end{array}$ & Percent & $\begin{array}{c}\text { Projections } \\
\mathbf{2 0 1 0}\end{array}$ & Percent & $\begin{array}{c}\text { Projections } \\
\mathbf{2 0 2 5}\end{array}$ & Percent \\
\hline $\mathbf{6 5 - 7 4}$ & 50,525 & 47.4 & 60,110 & 49.1 & 99,626 & 52.5 \\
\hline $\mathbf{7 5 - 8 4}$ & 41,864 & 39.2 & 43,486 & 35.5 & 66,236 & 34.9 \\
\hline $\mathbf{8 5}$ and over & 14,273 & 13.4 & 18,899 & 15.4 & 23,836 & 12.6 \\
\hline Total & 106,662 & 100 & 122,495 & 100 & 189,698 & 100 \\
\hline
\end{tabular}

*Source: Bureau of Business and Economic Research, 2003

Public Transportation

Sarasota County Area Transit (SCAT) is an agency within Sarasota County Government. The system is governed by the Board of County of Commissioners, which consists of five elected officials. SCAT serves the urbanized areas of Sarasota County with both fixedroute motorbus and demand-response service. The service area population of SCAT was 308,043 during FY 2002. During that time, the service area population density was 1,937 persons per square mile. The weekday span of service offered by SCAT is 15.4 hours. SCAT carried 1,718,370 passengers in 2003.

\section{Paratransit Services}

Sarasota County has 5,284 certified ADA users in their service area. Ten percent of the certified ADA users also access fixed route service, with 4,500 only accessing paratransit service. Approximately 381 (7 percent) of certified ADA users currently do not live within the service area.

Table 44. Paratransit Ridership Data, SCAT

\begin{tabular}{|c|c|}
\hline Year & \# of Certified ADA Users \\
\hline 2000 & 4,838 \\
\hline 2001 & 5,012 \\
\hline 2002 & 5,247 \\
\hline 2003 & 5,377 \\
\hline
\end{tabular}


Table 45. Number of Paratransit Trips Made per Year, SCAT

\begin{tabular}{|c|c|}
\hline Year & \# ADA Trips/Year \\
\hline 2000 & 82,257 \\
\hline 2001 & 85,212 \\
\hline 2002 & 89,215 \\
\hline 2003 & 91,414 \\
\hline 2004 & 89,832 \\
\hline \multicolumn{2}{|c|}{ Source: CUTR Survey } \\
\hline
\end{tabular}

To determine ADA eligibility, Sarasota County uses the following process. The application is screened by Sarasota County and is then reviewed by Easter Seals. The client, if found eligible, is then entered as certified in the software and is informed of their eligibility.

The fare per ADA trip is $\$ 1.00$, while the actual cost per ADA trip is $\$ 18.34$. The fixed route fare is $\$ 0.50$. To compensate for ADA paratransit services when hours vary, ADA service begins one hour before any route begins and ends when service on all routes have ended. Half of ADA paratransit services are provided in-house. SCAT's fleet consists of 36 vehicles, with the average cost ranging from $\$ 118-125,000$. SCAT assigns two fulltime mechanics to its ADA fleet. Half of all trips are brokered through 19 different providers.

Table 46. Costs of Operating ADA Paratransit Service, SCAT

\begin{tabular}{|l|l|l|l|l|}
\hline Year & \multicolumn{1}{|c|}{ In-house } & $\begin{array}{c}\text { Maintenance } \\
\text { Costs }\end{array}$ & $\begin{array}{c}\text { Operation } \\
\text { Costs }\end{array}$ & Cost/Trip \\
\hline $\mathbf{2 0 0 0}$ & SCAT & $\$ 64,012$ & $\$ 1,339,483$ & $\$ 16.28$ \\
\hline $\mathbf{2 0 0 1}$ & SCAT & $\$ 86,137$ & $\$ 1,476,604$ & $\$ 17.33$ \\
\hline $\mathbf{2 0 0 2}$ & SCAT & $\$ 94,667$ & $\$ 1,593,371$ & $\$ 17.86$ \\
\hline $\mathbf{2 0 0 3}$ & SCAT & $\$ 55,954$ & $\$ 1,645,413$ & $\$ 18.34$ \\
\hline
\end{tabular}

Methodology for Forecasting Paratransit Demand

SCAT experienced a trend of increasing demand for paratransit service. The demand has historically grown three to four percent annually. During the planning process, however, SCAT has forecasted their demand by multiplying the figure recorded by the previous year by five percent. Recently (2003-2004), SCAT has implemented cost-saving measures and policies in order to more effectively manage costs associated with paratransit service. This resulted in a decrease of 2 percent in 2003-2004. Demand is now expected to decrease 2 percent annually. 
Table 47. Forecasted Values for ADA Ridership, SCAT

\begin{tabular}{|l|l|l|}
\hline Year & $\begin{array}{l}\text { Estimated ADA Paratransit } \\
\text { Ridership }\end{array}$ & $\begin{array}{l}\text { Methodology Used to Determine } \\
\text { Number }\end{array}$ \\
\hline 2001 & 86,370 & 5\% estimated increase \\
\hline 2002 & 89,473 & 5\% estimated increase \\
\hline 2003 & 93,676 & 5\% estimated increase \\
\hline 2004 & 88,900 & 5\% estimated decrease \\
\hline
\end{tabular}

Source: CUTR Survey

There are four cost saving measures that have been implemented by SCAT to alleviate a portion of the demand on paratransit trips. A brief description of these measures is described below.

SCAT-About

SCAT-About, which began service in 2002, has quickly become a very useful and beneficial service. The service operates on Venice Island, an area that has a predominately retired population, and acts as a point deviated circulator, arriving at a time point once an hour where users can then transfer to fixed-route. SCAT-About provides curb to curb service to patrons that call and schedule a pick up 24 hours in advance. If there is availability, patrons may be able to schedule a pickup up to two hours in advance. It is estimated that approximately 40 percent of users of this service were formerly paratransit users. During the first year of operation, ridership levels were relatively low, yet each year the number of patrons has greatly increased.

\section{Town-to-Town}

Implemented in 2005, Town to Town service divides a paratransit user's trip into segments between paratransit and fixed-route. With this service, paratransit riders may be picked up at their origin with a paratransit van and brought to one of four locations where the user can then transfer to a fixed-route bus. These four locations include WalMart, the Venice Train Depot, Sarasota Mall, and Sarasota Hospital. After accessing the fixed-route system, if needed the user is then met by another paratransit vehicle at a predetermined location to complete their one-way trip. This service has allowed for cost savings per paratransit trip. Trips that used to cost SCAT \$51.31 now may only cost $\$ 12.00$ or $\$ 13.00$. This technique while helping to reduce costs may not necessarily reduce the number of paratransit trips. 
Currently the service operates in a south to north direction, and has been made possible by adding an eight minute dwell time at the four locations for the fixed-route. SCAT is planning on implementing a complementary route providing service in a north to south direction. During January 2005, 54 trips were made using this service. The number increased to 100 in February and 150 in March.

Stop Improvements

SCAT identified 24 fixed-route stops to make ADA accessible. The intention of improving the stops is to increase the use of fixed-route service among ADA certified individuals. In order to achieve this goal, paratransit vehicles pick up a customer and transport them to one of the 24 designated stops. The passenger then completes their trip by riding the fixed-route system to their destination.

SCAT determined which stops should become "preferred", based upon their fulfillment of two criteria:

- More than one route must service the stop

- There must be adequate spacing available for paratransit vehicles to stop and deploy a lift without affecting other traffic.

Some of the improvements made to the stops are to include the addition of benches, shelters, and pads. The process of improving the stops is approximately 20 percent complete. As with the town-to-town service, this technique may help to reduce costs, but may not necessarily reduce the number of paratransit trips.

\section{Moving On Up}

For about one year, SCAT has provided an aggressive bus pass program for ADA certified riders. Moving on Up is a program that provides free monthly passes for fixedroute offering an unlimited number of trips to ADA certified users. The purpose of the program is to decrease the demand on paratransit trips and increase the independence of ADA riders. The riders are able to determine which trips they will travel on fixed-route and on paratransit vehicles, based on their assessment of safety and other considerations. Approximately 15 people have currently volunteered to participate in the program and have found that it works well. 


\section{Other Improvements}

SCAT has implemented a number of other policies in an effort to decrease the demand on paratransit travel. SCAT currently contracts with Easter Seals to act as a paratransit coordinator. The responsibilities of the coordinator include the determination of ADA eligibility, and participation in travel training. The coordinator now spends two days a week at SCAT, completing the above mentioned tasks and also learning about the fixedroute schedule. This effort has increased the coordinators' knowledge and understanding of the system, and since has been able to make decisions that are more efficient in paratransit travel.

SCAT has also determined a goal of moving 10 percent of paratransit trips over to the fixed-route system between July 2005 and June 30, 2006. It is intended that the above mentioned steps that SCAT has implemented will help in the achievement of this goal. In addition, SCAT will also be using Route Itinerary software, which will help the paratransit coordinator and other staff provide detailed travel information to persons wanting to access the fixed-route system. Colored maps and detailed directions are produced by the software. Route Itinerary will be integrated with Trapeze, which is the current software employed by SCAT for transit operations. 


\section{Volusia County - VOTRAN}

Location

Situated on the east coast of Central Florida, Volusia County consists of 1,105 square miles. The surrounding counties are Brevard and Seminole to the south, Marion and Lake to the west, and Flagler to the north. The county is approximately 250 miles north of Miami and 89 miles south of Jacksonville.

Population and Demographics

Volusia County is the $14^{\text {th }}$ densest county in the state, with 416 persons per square mile. There are 17 municipalities in the county and 18 recognized local governments including the unincorporated county. The largest cities are Deltona (population 69,543) and Daytona Beach $(64,112)$ followed by Port Orange $(45,823)$ and Ormond Beach $(36,301)$ (BEBR, 2003).

In 2000, 443,343 people resided in the county, which represented an increase of 19.6 percent from the population recorded in 1990 (370,737) (U.S. Census Bureau). Estimates based upon the U.S. Census show a 3.7 percent change in the population between 2000 and 2002 (BEBR, 2003).

Age

The median age of residents within Volusia County is 43.2 compared to the median age of 39.4 for the state of Florida. The median age is projected to increase to 48.7 by 2020 (BEBR, 2003). As shown in Table 48., the largest percentage of persons is between the ages of 45 and 64 (25.4 percent).

Table 48. 2002 Estimates of Persons by Age Group in Volusia County

\begin{tabular}{|l|c|c|}
\hline Age & Population & Percent \\
\hline $\mathbf{0 - 1 4}$ & 74,344 & 16.2 \\
\hline $\mathbf{1 5 - 2 4}$ & 55,706 & 12.1 \\
\hline $\mathbf{2 5 - 4 4}$ & 111,890 & 24.3 \\
\hline $\mathbf{4 5 - 6 4}$ & 116,987 & 25.4 \\
\hline $\mathbf{6 5}$ and over & 100,810 & 21.9 \\
\hline Total & 459,737 & 100.0 \\
\hline
\end{tabular}

*Source: Bureau of Business and Economic Research, 2003 
As shown in Table 49., approximately 50 percent of the population aged 65 and older is between the ages of 65 to 74. This percentage is expected to increase to 51.5 by 2010 . The percentage of residents in the County aged 65 and older is 22.3 percent.

Table 49. Persons Aged 65 and Older Population and Projections in Volusia County

\begin{tabular}{|l|c|c|c|c|c|c|}
\hline Age & $\begin{array}{c}\text { Population } \\
\mathbf{2 0 0 2}\end{array}$ & Percent & $\begin{array}{c}\text { Projections } \\
\mathbf{2 0 1 0}\end{array}$ & Percent & $\begin{array}{c}\text { Projections } \\
\mathbf{2 0 2 5}\end{array}$ & Percent \\
\hline $\mathbf{6 5 - 7 4}$ & 50,619 & 50.2 & 59,119 & 51.5 & 102,698 & 55.5 \\
\hline $\mathbf{7 5 - 8 4}$ & 37,913 & 37.6 & 39,288 & 34.2 & 61,160 & 33.1 \\
\hline $\mathbf{8 5}$ and over & 12,278 & 12.2 & 16,478 & 14.3 & 21,126 & 11.4 \\
\hline Total & 100,810 & 100 & 114,885 & 100 & 184,984 & 100 \\
\hline
\end{tabular}

*Source: Bureau of Business and Economic Research, 2003

Public Transportation

VOTRAN is funded through the Volusia County Commission's General Fund and it is managed by the MacDonald Transit Corporation. It is governed by a Board of Directors that is made up of seven County Council members. Public transportation services provided by VOTRAN include fixed-route motorbus, paratransit, and vanpools. The service area population for 2002 was 443,343. The service area density was 367 persons per square mile. Weekday span of service is 12.4 hours. The total number of riders of the fixed route service for fiscal year 2003 was 2,643,918.

\section{Paratransit Services}

VOTRAN has 3,396 paratransit users in its service area. Information about the number of riders in each of the past 4 years was not tracked annually. Information is not available about the number of certified ADA users that access fixed route service or the number of users that live outside of the service area. 
Table 50. Number of Paratransit Trips Made per Year, VOTRAN

\begin{tabular}{|c|c|}
\hline Year & \# ADA Trips/Year \\
\hline 2000 & 103,224 \\
\hline 2001 & 107,387 \\
\hline 2002 & 122,041 \\
\hline 2003 & 131,258 \\
\hline 2004 & 135,995 \\
\hline \multicolumn{2}{|c|}{ Source: CUTR Survey } \\
\hline
\end{tabular}

To determine ADA eligibility, VOTRAN uses the following process. An application, which is available in both English and Spanish, must be completed by an applicant. Completed applications are then reviewed by VOTRAN staff and the department supervisor to determine eligibility. Telephone interviews and/or functional assessments may be used to get a better understanding of limitations. If an applicant is denied, a letter is sent notifying the customer and explaining the appeals process. If an applicant is approved, a letter is sent with a user guide.

The fare per ADA trip is $\$ 2.00$, while the actual costs are $\$ 13.84$ per ambulatory trip and $\$ 21.86$ per wheelchair trip. The base fare is $\$ 1.00$ for the fixed route system (half fare for seniors, disabled, and children). ADA service is available during all hours that fixedroutes operate for all areas included within a $3 / 4$ mile of all transit corridors. ADA paratransit services are provided partially through a broker. The VOTRAN paratransit fleet consists of 43 vehicles with an average age of 3.5 years and average cost of $\$ 68,000$. There are 31 individuals on their maintenance staff.

Table 51. Costs of Operating ADA Paratransit Service, VOTRAN

\begin{tabular}{|l|l|l|l|l|}
\hline Year & $\begin{array}{c}\text { Contractor } \\
\text { name or in- } \\
\text { house }\end{array}$ & $\begin{array}{c}\text { Maintenance } \\
\text { Costs }\end{array}$ & $\begin{array}{c}\text { Operation } \\
\text { Costs }\end{array}$ & Cost/Trip \\
\hline $\mathbf{2 0 0 1}$ & VOTRAN & $\$ 371,054$ & $\$ 1,814,316$ & $\$ 11.80$ \\
\hline $\mathbf{2 0 0 1}$ & Vendor & $\$ 272,972$ & $\$ 1,935,000$ & $\$ 19.16$ \\
\hline $\mathbf{2 0 0 2}$ & VOTRAN & $\$ 363,578$ & $\$ 1,706,971$ & $\$ 15.02$ \\
\hline $\mathbf{2 0 0 2}$ & Vendor & $\$ 266,928$ & $\$ 1,921,880$ & $\$ 28.09$ \\
\hline $\mathbf{2 0 0 3}$ & VOTRAN & $\$ 471,894$ & $\$ 1,962,449$ & $\$ 15.75$ \\
\hline $\mathbf{2 0 0 3}$ & Vendor & $\$ 204,027$ & $\$ 1,535,475$ & $\$ 20.02$ \\
\hline
\end{tabular}


Methodology for Forecasting Paratransit Demand

To forecast ADA paratransit ridership for VOTRAN's service area, a number of factors are considered. The forecasted demand for all paratransit service is determined by major funding sources, such as ADA, Transportation Disadvantaged, Medicaid, etc. Historical trends such as ridership data are evaluated and projected service changes are considered as well.

Table 52. Forecasted Values for ADA Ridership, VOTRAN

\begin{tabular}{|l|c|}
\hline Year & Estimated ADA Paratransit Ridership \\
\hline 2002 & 303,567 \\
\hline 2003 & 292,856 \\
\hline 2004 & 313,286 \\
\hline \multicolumn{2}{|c|}{ Source: CUTR Survey } \\
\hline
\end{tabular}




\section{Summary of Survey Results}

A total of 13 transit agencies were surveyed either by mail or over the telephone during the Summer and Fall of 2004. While the previous pages outline the survey response in detail, this section summarizes overall results.

Of the agencies surveyed, all 13 utilized historical data to forecast their paratransit demand. Table 53 summarizes the type of data used to forecast demand among the surveyed agencies and a particular measure that is applied, if applicable.

Table 53. Data and Forecasting Methods Utilized by Agencies for Estimating Demand

\begin{tabular}{|c|c|c|}
\hline Transit Agency & Data Used & Forecasting method \\
\hline $\begin{array}{l}\text { Broward County Transit } \\
\text { (BCT) }\end{array}$ & Historical trends: past ridership & Yearly increase of 5 percent \\
\hline $\begin{array}{l}\text { Dallas Area Rapid Transit } \\
\text { (DART) }\end{array}$ & Revenue hours, productivity values & $\begin{array}{l}\text { The multiplication of revenue } \\
\text { hours by a determined } \\
\text { productivity value }\end{array}$ \\
\hline $\begin{array}{l}\text { Escambia County Area } \\
\text { Transit (ECAT) }\end{array}$ & Historical trends: past ridership & Yearly increase of 9 percent \\
\hline King County Metro & $\begin{array}{l}\text { Historical trends: ridership, population data, } \\
\text { income levels, policy changes, fare increases, } \\
\text { number of zero denials, percentage of } \\
\text { conditional eligibility }\end{array}$ & $\begin{array}{l}\text { Percentage values are applied to } \\
\text { each considered variable }\end{array}$ \\
\hline $\begin{array}{l}\text { Manatee County Area } \\
\text { Transit (MCAT) }\end{array}$ & Historical trends: past ridership & \\
\hline New York City Transit & Historical trends: past ridership & \\
\hline $\begin{array}{l}\text { Orange County Transit } \\
\text { Authority (OCTA) }\end{array}$ & $\begin{array}{l}\text { Historical trends, Census information, } \\
\text { community trends }\end{array}$ & $\begin{array}{l}\text { Method produced by consultant } \\
\text { study (see p. } 31 \text { ) }\end{array}$ \\
\hline $\begin{array}{l}\text { Pasco County Public } \\
\text { Transportation (PCPT) }\end{array}$ & $\begin{array}{l}\text { Historical and current data: ridership trends, } \\
\text { population data (including age), income levels }\end{array}$ & \\
\hline $\begin{array}{l}\text { Pinellas Suncoast Transit } \\
\text { Authority (PSAT) }\end{array}$ & Historical trends: past ridership & \\
\hline $\begin{array}{l}\text { Polk County Intercity } \\
\text { Transit (including Winter } \\
\text { Haven Area Transit) }\end{array}$ & Historical trends & \\
\hline $\begin{array}{l}\text { Regional Transit System } \\
\text { (RTS) }\end{array}$ & Historical trends: past ridership & Yearly increase of 10 percent \\
\hline $\begin{array}{l}\text { Sarasota County Area } \\
\text { Transit (SCAT) }\end{array}$ & Historical trends: past ridership & Yearly increase of 5 percent \\
\hline VOTRAN & $\begin{array}{l}\text { Historical trends (past ridership) and project } \\
\text { service changes }\end{array}$ & \\
\hline
\end{tabular}


Of these 13 agencies, five applied a particular measure to forecast their increase each year. These agencies included SCAT, OCTA, King County, VOTRAN, and DART. Four agencies analyzed historical data and applied a percent increase on a yearly basis. In each of these cases, the agencies applied historical data that is unique to their service area. While the majority of these agencies explained their use of historical data as including ridership trends, only a few considered additional factors such as the age of the population and income levels as the Orange County Transportation Authority.

Of those surveyed, a small portion was able to provide information that is essential to assist in assessing the most effective methodology used for forecasting paratransit demand. This data includes the value for both the number of trips made each year and the estimated value determined by the forecasting method that had been employed. The agencies that recorded this data include Sarasota County Area Transit (SCAT), VOTRAN (Volusia County), Dallas Area Regional Transit (DART), and King County Metro. An analysis of the forecasted demand for each of these agencies follows.

\section{Dallas Area Regional Transit (DART)}

DART provided values for the actual number of trips made and the forecasted demand for 2000 through 2003. The methodology that was used to estimate the forecasted demand was not provided for the values between 2000 and 2003. A new methodology that has been established for the agency was applied to ridership data for 2004. This methodology first establishes values for productivity and revenue hours. These two values are multiplied, and an end result is used.

Table 54. Difference between Actual Trips and Forecasted Demand, DART

\begin{tabular}{|l|c|c|c|}
\hline $\begin{array}{l}\text { Year } \\
\text { (FY) }\end{array}$ & Actual Ridership & Estimated Demand & Difference \\
\hline 2000 & 559,088 & 610,190 & $\mathbf{- 8 . 4 \%}$ \\
\hline 2001 & 547,055 & 515,200 & $\mathbf{- 5 . 9 \%}$ \\
\hline 2002 & 585,711 & 511,290 & $\mathbf{- 2 . 9 \%}$ \\
\hline 2003 & 577,312 & 594,440 & $\mathbf{2 . 9 \%}$ \\
\hline 2004 & 683,743 & 602,138 & $\mathbf{- 1 2 . 0 \%}$ \\
\hline
\end{tabular}




\section{Graph 1. Difference between Actual Trips and Forecasted Demand, DART}

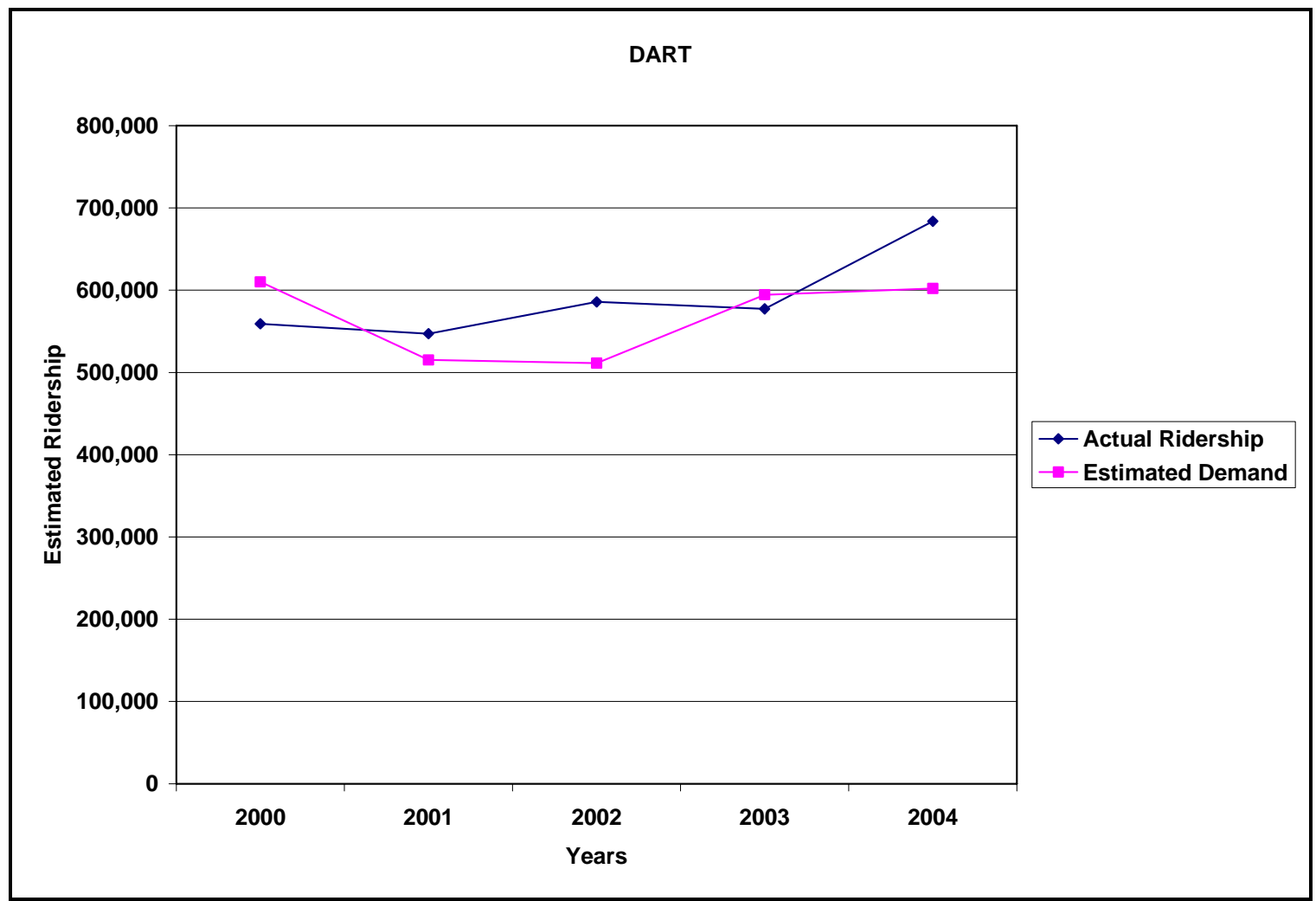

King County

King County provided information for the number of actual trips and the estimated demand for 2000 through 2003. The paratransit demand is forecasted in King County by utilizing a variety of area-based information. Population and demographic data, as well as fare increases, policy changes, zero denials, and the implementation of conditional eligibility are considered. For the year 2000, ridership demand was overestimated by approximately 31,000, while the forecasted values for latter years were underestimated.

Table 55. Difference between Actual Trips and Forecasted Demand, King County

\begin{tabular}{|l|c|c|c|}
\hline Year & Actual Trips & Estimated Demand & Difference \\
\hline 2000 & 998,624 & $1,029,592$ & $\mathbf{3 . 1 \%}$ \\
\hline 2001 & 976,707 & 969,997 & $\mathbf{1 . 0 \%}$ \\
\hline 2002 & 991,464 & 956,803 & $\mathbf{4 . 5 \%}$ \\
\hline 2003 & $1,024,491$ & $1,004,556$ & $\mathbf{2 . 0 \%}$ \\
\hline 2004 & $1,062,092$ & $1,072,928$ & $\mathbf{1 . 1 \%}$ \\
\hline
\end{tabular}




\section{Graph 2. Difference between Actual Trips and Forecasted Demand, King County}

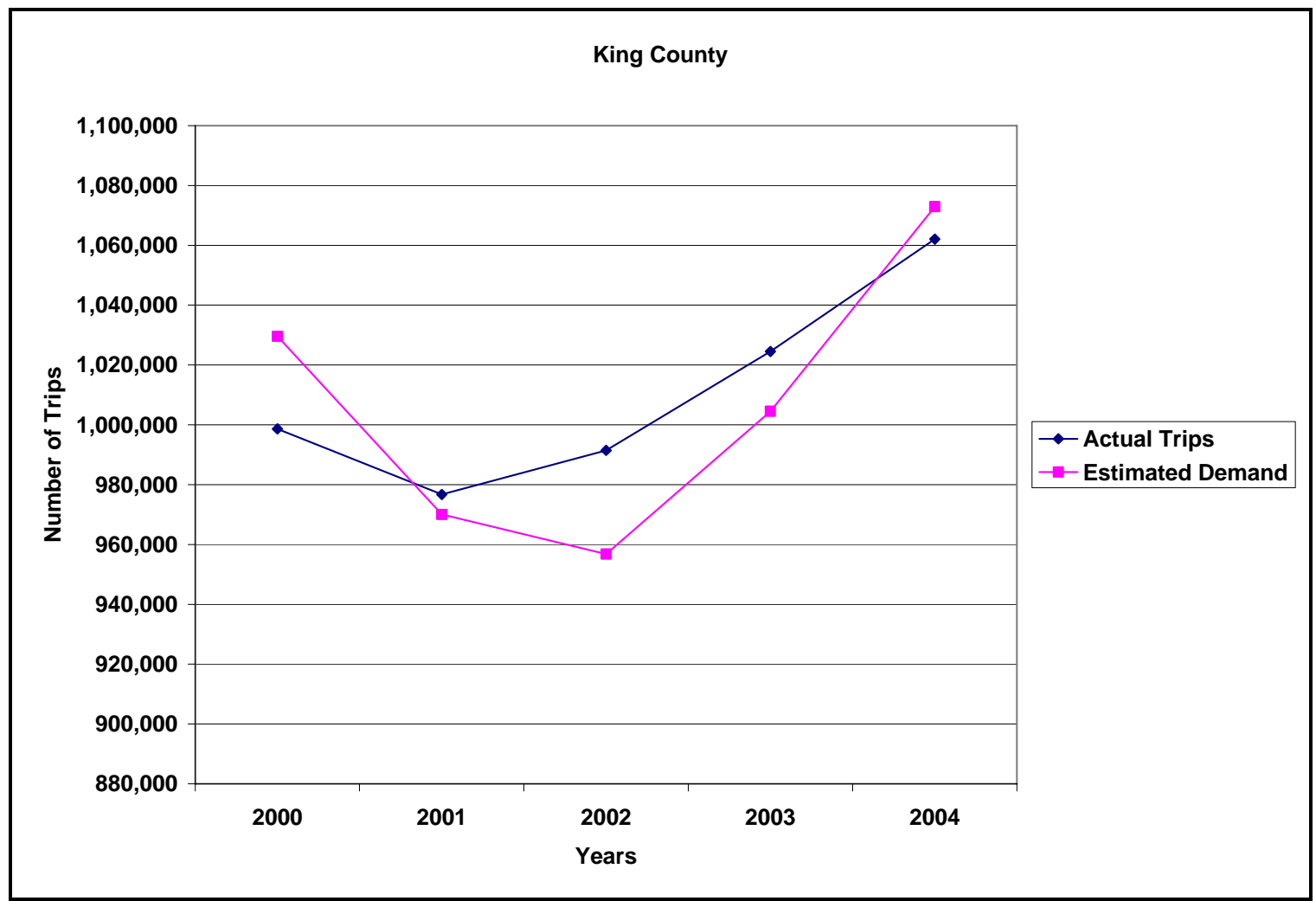

Orange County Transportation Authority (OCTA)

Orange County was able to provide information for the number of trips taken in 2004 (by fiscal year) and the forecasted value for that same year. Based on the information provided, the forecasted demand for paratransit services for 2004 had a three percent difference than the actual number of trips taken. This value was determined by utilizing a consultant study that was conducted in 2003 to determine an efficient methodology for forecasting demand. The study developed a time series model, which is based upon a multi-variable regression analysis that incorporates variables of historical growth trends, holidays, time of year, day of the week, and recent trend experience. A detailed explanation of this model has been provided in the section of this report that summarized information received during the survey process. 
Table 56. Difference between Actual Trips and Forecasted Demand, OCTA

\begin{tabular}{|l|c|c|c|}
\hline Year & Actual Trips & Estimated Demand & Difference \\
\hline 2004 & $1,085,329$ & $1,060,101$ & $\mathbf{3 \%}$ \\
\hline
\end{tabular}

Sarasota County Area Transit (SCAT)

Between 2001 and 2003, SCAT forecasted their demand by analyzing historical trends and applying a five percent increase to the ridership of the previous year. The agency implemented cost saving measures to decrease the demand for ADA/paratransit trips during FY 2003 and 2004. These measures resulted in SCAT forecasting a five percent decrease in demand for the following year. The actual percent decrease for that year was two percent. SCAT expects to witness a two percent decrease yearly for future demand.

As shown in Table 57., the values calculated for ridership demand were relatively close to the actual number of trips for each respective year. During 2004, however, the forecasted demand was not as large as the actual demand. During 2004, however, the forecasted demand was not sufficient based upon the actual demand. Graph 3. also illustrates these values.

Table 57. Difference between Actual Trips and Forecasted Demand, SCAT

\begin{tabular}{|l|c|c|c|}
\hline Year & Actual Trips & Estimated Demand & Difference \\
\hline 2001 & 85,212 & 86,370 & $\mathbf{1 . 4 \%}$ \\
2002 & 89,215 & 89,473 & $\mathbf{0 . 3 \%}$ \\
\hline 2003 & 91,414 & 93,676 & $\mathbf{2 . 5 \%}$ \\
2004 & 89,832 & 88,900 & $\mathbf{- 1 . 1 \%}$ \\
\hline
\end{tabular}




\section{Graph 3. Difference between Actual Trips and Forecasted Demand, SCAT}

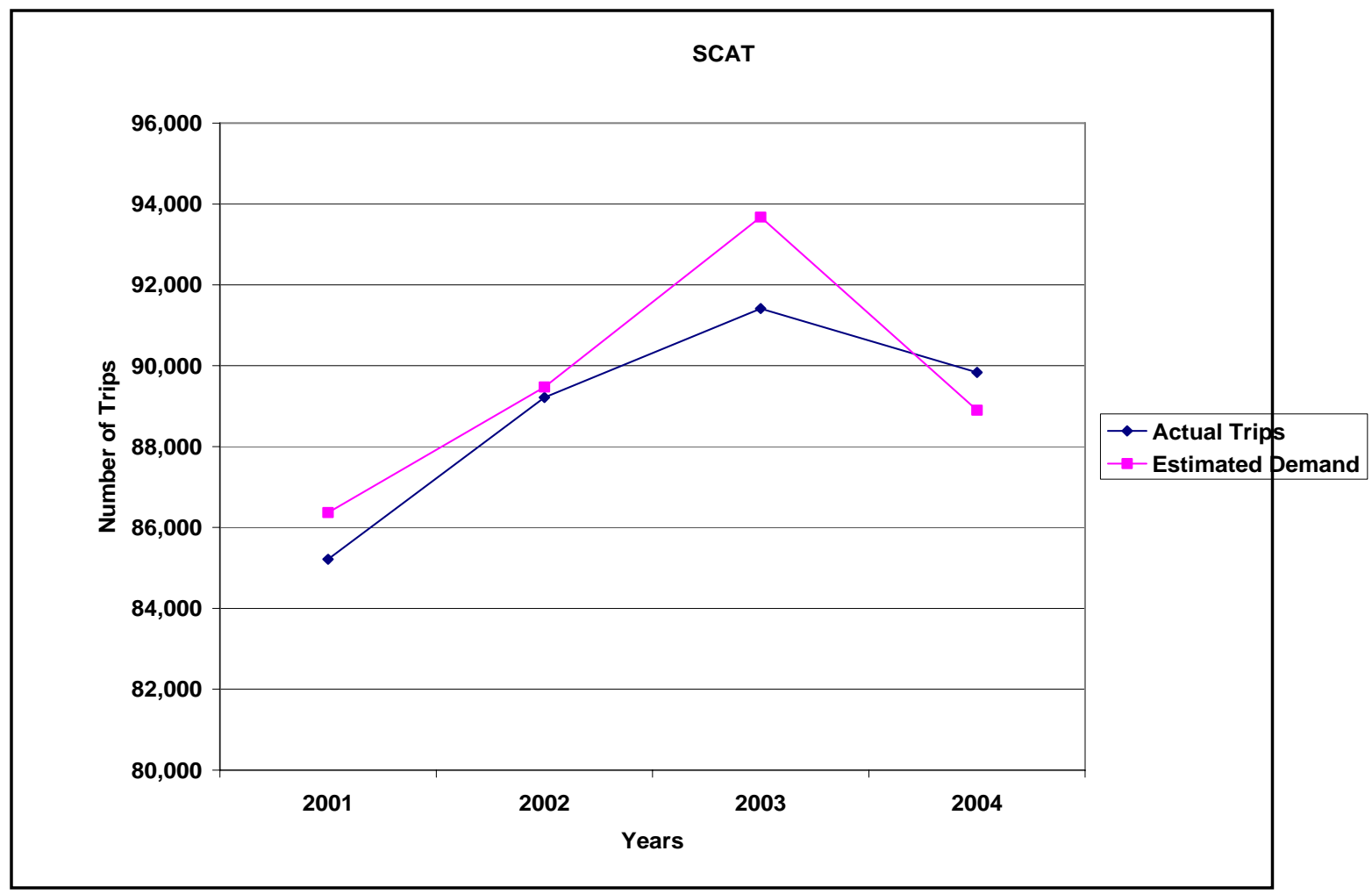

\section{VOTRAN (Volusia County)}

Values for forecasted paratransit demand were recorded by VOTRAN for 2002 through 2004. The method that was used to forecast demand included an evaluation of historical data and trends. In addition, projected changes in service were considered as well. Major funding sources (including ADA, Transportation Disadvantaged, and Medicaid) determined these forecasted values. The average difference between actual trips and forecasted valued is 180,281 . The largest difference between the actual trip value and the forecasted value was for 2003, with a difference of 182,028.

Table 58. Difference between Actual Trips and Forecasted Demand, VOTRAN

\begin{tabular}{|l|c|c|c|}
\hline Year & Actual Trips & Estimated Demand & Difference \\
\hline 2002 & 122,041 & 303,567 & $\mathbf{5 9 . 8 \%}$ \\
\hline 2003 & 131,258 & 292,856 & $\mathbf{5 5 . 2 \%}$ \\
\hline 2004 & 135,995 & 313,286 & $\mathbf{5 6 . 6 \%}$ \\
\hline
\end{tabular}


Graph 4. Difference between Actual Trips and Forecasted Demand, VOTRAN

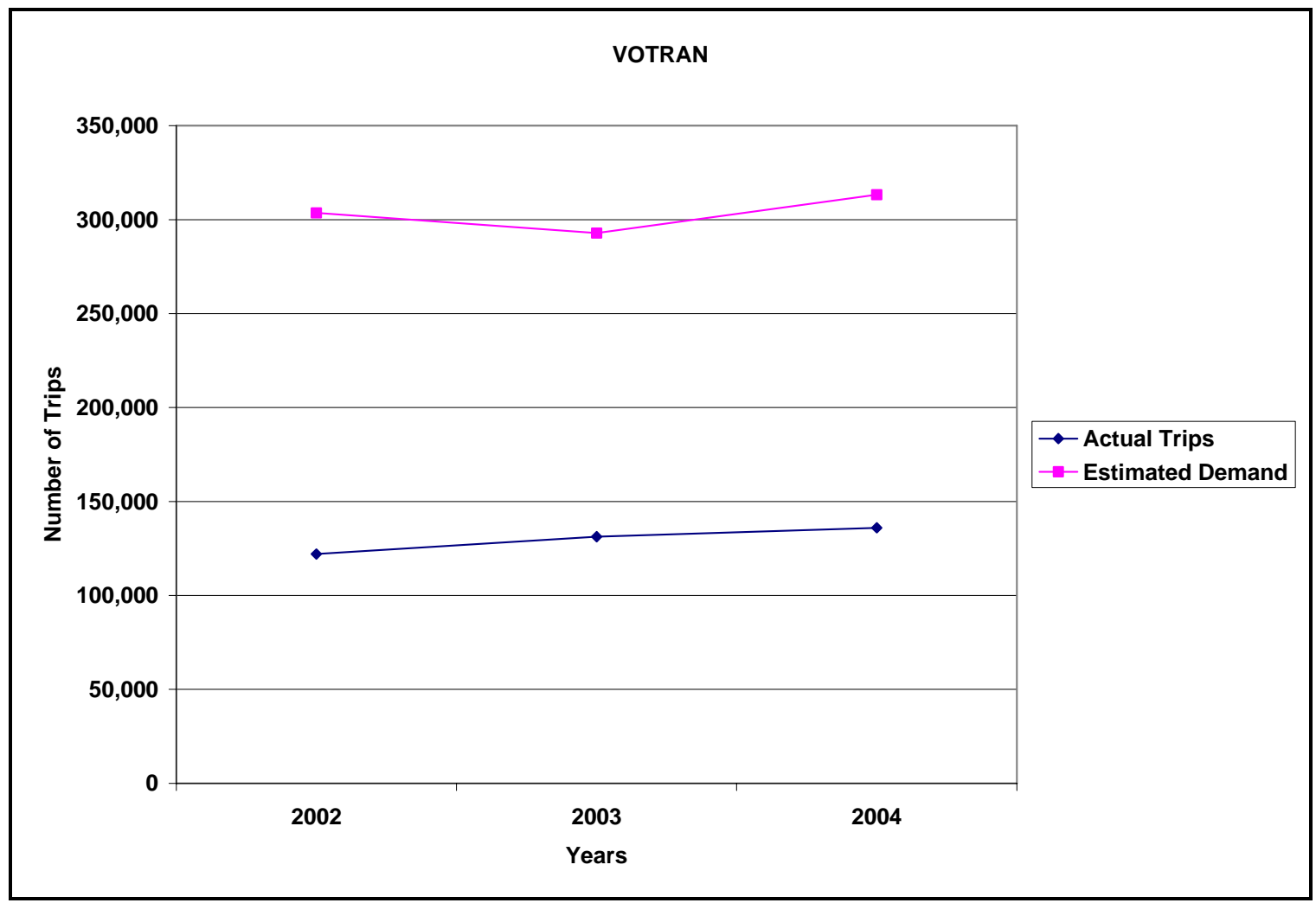




\section{Findings and Recommendations}

The purpose of this research project, conducted for FDOT by CUTR as part of the NCTR Program, was to evaluate how transit agencies forecast their demand for paratransit ridership, and to assess which methodologies were the most efficient to determine this value. It was originally planned for this project to determine a methodology for transit agencies to employ for their use.

This project included four separate tasks that were intended to achieve the objectives listed above. First, a literature review was conducted pertaining to current methods of forecasting demand in the transit industry. In addition to conducting the literature review, background information, such as that provided by the U.S. Census Bureau and transit agencies, was to be gathered in order to provide a comprehensive overview of each agency that was included in the research. Following these tasks, additional information was obtained through the survey process, which had the overall intention of gathering information regarding methodologies employed by transit agencies to forecast their paratransit demand. The survey findings resulted in an understanding of factors that are considered when agencies determine their demand. The last task of this project utilized the results of the previous tasks to develop a synthesis of the best practices in the evaluation of methodologies. Benefits and challenges related to the presented methodologies are noted. Finally, recommendations are presented to assist the transit industry in determining the proper methodologies that may be useful to forecast their paratransit demand.

It should also be noted that the original intention of this project was to formulate a methodology that transit agencies may use to forecast demand. Prior to the commencement of the project, however, it was learned that a similar project with this objective was proposed by the Transit Cooperative Research Program (TCRP) and it was therefore determined that this project would not complete this task. The TCRP project will conduct a more comprehensive evaluation of transit agencies throughout the U.S. and determine a methodology that may be applied by each agency. The findings and recommendations presented in this project may assist in this task.

While this study sought to separate the best practices for forecasting paratransit demand, very few cases were found where transit agencies recorded the necessary information to conduct a sufficient evaluation to make a confident assessment on which methodologies should be used. In addition, while the majority of agencies reported their method of 
forecasting demand as analyzing historical data, a particular strategy for using this information was not provided. As such, it is difficult to assess the accuracy of the methodologies used and their impacts on the agencies' planning process.

It was also found that a general assessment of the methodologies may not benefit every agency. For example, Sarasota County Area Transit (SCAT) reported that the demand for paratransit service increases by three to four percent annually, enabling them to apply a systematic percent increase to determine their forecasted demand. In addition, the information provided by SCAT illustrates that their methodology is the most effective in determining accurate results. Other agencies, however, may not experience the regular annual increase as SCAT, and may therefore find that this methodology may not be sufficient.

One additional consideration to this project is the inability of transit agencies to report methodologies that are currently used, or that had been previously employed. Without this information, an analysis of the effectiveness of their forecasted values cannot be conducted.

Overall, while difficult to assess the actual method in which data is used, many transit agencies utilize historical data to forecast demand. As found in the survey results, however, the type of historical data that is used varies from each agency. Some agencies reported using ridership trends, while other agencies mentioned the inclusion of additional data, such as demographic information and fare increases. The experiences and lessons learned as part of this effort may provide insight to other transit agencies contemplating changes in their current methods of forecasting demand. The following is a list of recommendations that transit agencies should consider when contemplating such changes, based on the findings of this project:

- The practice of determining user's eligibility as either conditional or fully eligible plays a significant role in effecting paratransit demand. If users are only conditionally eligible, they are not able to access the system as frequently as those who are determined fully eligible.

- The percentage of ADA certified users that may access fixed-route service is a consideration. An agency with a high percentage of these users may consider decreasing their demand values. 
- Population information is an important factor to consider for demand estimation. The increase or decrease in the service area population may have a large or marginal effect on demand. Additional information regarding the population, such as current values and projections for the elderly, should also be considered when evaluating the need for paratransit service. While this seems obvious, few agencies reported taking this into account.

- The size of the agency is an issue. Many smaller agencies with a service area significantly smaller than the county may not have access to comprehensive demographic information such as that produced by the U.S. Census Bureau, as most of the data is applied to an entire county and may not be specific enough for the agency's local needs.

- The cost incurred by a user of the paratransit system may have an effect on demand as well. As research has shown, an increase in paratransit fares may result in an increase in the number of ADA users utilizing the fixed-route system (Koffman 1997).

- Income levels of the service population may also have a role in determining actual demand. As previously referenced, passengers that cannot afford fares associated with paratransit trips may not utilize the service (Koffman 1997).

- The convenience of use for passengers should also be a consideration when estimating demand for services. Previous research has shown that passengers that are pleased with the service are more likely to utilize it than passengers that are not. Issues that may affect the level of satisfaction are reliability, ontime performance, and safety.

- The provision of a point deviation service will likely have a significant effect on the demand for paratransit service. The implementation of SCAT-About in Sarasota resulted in a decrease in paratransit demand, conveying its valuable role. While transit agencies may not want to incur the cost of providing a similar system, the overall expenditure for paratransit may decrease significantly over time, and therefore justify the cost of the point deviated service. 


\section{References}

1. Florida Statistical Abstract 2003, Bureau of Economic and Business Research, the University of Florida.

2. Koffman, D., Lewis, D., Forecasting Demand for Paratransit Required by the Americans with Disabilities Act, Transportation Research Record 1571, 1997.

3. Menninger-Mayeda, et.al., ADA Demand Forecasting for Orange County Transportation Authority’s Access Program, January 2004.

4. $\quad$ S.G. Associates, et. al., Workbook for Estimating Demand for Rural Passenger Transportation, Transit Cooperative Research Program, TCRP Report 3, 1995.

5. Weiner, Richard, Poultney, N., Perrone, B., King County Keeps Moving:

Evaluating Best Practices in ADA Paratransit Eligibility, American Public Transportation Association, 2004. 